\title{
The Structural Sources of Association
}

\author{
Evan Schofer \\ Department of Sociology \\ University of California, Irvine \\ Wesley Longhofer \\ Department of Sociology \\ University of Minnesota \\ $\&$ \\ Goizueta Business School \\ Emory University
}

April 21, 2011

Word Count: 17,100 (including tables, references, etc.)

Direct correspondence to Evan Schofer (schofer@soc.uci.edu), 3151 Social Science Plaza, University of California - Irvine, Irvine, CA 92697 or Wesley Longhofer (long0324@umn.edu), Department of Sociology, University of Minnesota, 909 Social Sciences, $26719^{\text {th }}$ Ave South, Minneapolis, MN 55455. Work on this paper was supported by a Graduate Research Partnership Program grant from the University of Minnesota. We thank Beth Gardner, who generously shared data, as well as Liz Boyle, David Frank, Marion Fourcade, Joe Galaskieweicz, Joe Gerteis, Ann Hironaka, Doug McAdam, John Meyer, and anonymous AJS reviewers. We also received wonderful comments from members of the Irvine Comparative Sociology Workshop, the Minnesota Departmental Workshop, the Stanford Comparative Workshop, Emory's Organization \& Management Seminar, and colloquia at the University of North Carolina, Chapel Hill and Columbia University. 


\title{
The Structural Sources of Association
}

\author{
Abstract \\ Where do associations come from? One answer is that they are constructed by \\ individuals with high levels of resources and skills. Another answer is that associations \\ crystallize around a scaffolding of resources, opportunities, and cultural models rooted in \\ the state and world society. We argue the expansion and 'openness' of state institutions \\ encourage the formation of associations. Moreover, the institutional structures of world \\ society provide resources and legitimation, supporting the formation of domestic \\ association around the globe. Longitudinal cross-national data on voluntary associations \\ are analyzed using panel models with fixed effects to address unobserved heterogeneity \\ and instrumental variables models to address possible endogeneity. Wealthy and highly \\ educated societies have more associations, consistent with classic views. Institutional \\ features of the state, including overall expansion and openness (i.e., democracy, \\ decentralization) are also linked to higher levels of association. And, nations more \\ strongly tied to world society and those receiving international resources devoted to civil \\ society have more associations. Also, the expanding structure of world society is \\ correlated with growth of association over time. Finally, the impact of these factors \\ varies across types of association. Democracy, for instance, encourages political \\ association but not recreational groups. National ties to world society most strongly \\ affect associations whose aims tend to mirror the agendas of the international community. \\ These factors help make sense of the distinctive configurations of civil society found \\ around the globe.
}




\section{Introduction}

The past two decades have seen renewed interest in voluntary associations from across the social sciences, in large part due to Robert Putnam's emphasis on civic participation as an expression of social capital and a source of effective democratic governance (Putnam 1993, 2000). Historical trends in the density of associations and membership within the United States have garnered much attention (e.g., Putnam 2000; Skocpol and Fiorina 1999; Skocpol 2003; Andrews and Edwards 2004; Walker, McCarthy, and Baumgartner 2011). Yet, recent fluctuations within the United States pale in comparison to the variability in associational life that can be found across the world. We seek to understand this variability, and in so doing hope to answer one of the fundamental questions in the literature on civic engagement: What are the sources of association?

One answer is that associations emerge from society itself, a product of the capacities, skills, and values of the citizenry (Putnam 2000; Almond and Verba 1963) or due to a more general process of societal development, which is thought to generate such capacities (e.g., Inkeles and Smith 1976; Inglehart 1997). In contrast, a growing body of work attends to the broader structural and institutional factors that shape civic life: democratic institutions, state policy and law, institutionalized political culture, and so on (for instance, Paxton 2002; Skocpol and Fiorina 1999; Skocpol 2003; Schofer and Gourinchas 2001; Berman 1997; Reimann 2006). We draw on and extend this work to develop generalizable theoretical arguments regarding the ways that the state and transnational institutions shape domestic civic life. In doing so, we extend neo-institutional work on the world polity or "world society," which has largely focused on state policy 
isomorphism and less on the domestic political sphere. Finally, we discuss the possibility that macro-level factors generate differential ecological pressures on particular types of association, which may help explain the varying composition of associational life in societies across the globe.

We focus on two substantive issues: First, we argue that the expanding modern state is an engine that drives the growth of associations. Not only is the state a locus of resources, opportunities, and constraints that influence voluntary organizing, it is a key source of the identities, purposes, and legitimations that underlie civic life more generally. We draw opposition with a common theme in American conservative discourse: that a large and presumably overbearing state "crowds out" civic life (Joyce and Shambra 1996), and/or that associations spring up in times of economic or political crisis as the state pulls back, shrinks, or fails (e.g., Chazan 1994; Tripp 1997).

Second, we argue that world society plays a powerful role in supporting and empowering domestic associational activity worldwide. The international organizations, institutions, and culture that constitute a world polity or "world society" are a source of collective purposes, cultural models, resources, and political opportunities that encourage organizing. Moreover, the very idea of voluntary association has itself become quite fashionable within the international community as a panacea to a wide range of social ills. Associations have become a "taken-for-granted" good, and key international players channel attention and resources toward them. Particularly in the developing world, the impetus to form associations may be substantially exogenous to national societies.

Our empirical study is distinctive from the literature in two ways: First, we take a global purview. Prior cross-national studies typically focus on industrialized 
democracies, exploring variation among the societies where association is most common. Our world-wide sample draws a contrast between countries with widely varying levels of association (also see Paxton 2002; Salamon et al. 2004; Salamon and Anheier 1996, 1998; Anheier and Salamon 1998). We seek to understand the fundamental predictors of association rather than to explain a small portion of the variability at the high end.

Second, we examine country-level data on associations, rather than individuallevel membership. ${ }^{1}$ Prior research has focused on membership partly because such data is easier to collect. Yet, it also reflects the normative theme of the literature, which holds up individual participation as an ideal. The neo-Toquevillian tradition epitomized by Putnam has mainly seen associations as vehicles for individual participation rather than as important sociological phenomena unto themselves. So-called "checkbook" associations, nonmember advocacy organizations, lobbying groups, and the like are often viewed with suspicion, as potential threats to social capital and effective democracy (e.g., Weir and Ganz 1995; but see Walker, McCarthy, and Baumgartner 2011; Skocpol 2003).

We do not dispute the sociological import of individual participation, but we take cues from work by scholars of social movements and political sociology that highlight the importance of associations themselves. A growing body of work has turned the spotlight on advocacy organizations, professional social movement organizations, and the like, as important participants in national politics and policymaking (e.g., Andrews et al. 2010; Minkoff, Aisenbrey, and Agnone 2008; Minkoff and McCarthy 2005; Skocpol 2003; Reger and Staggenborg 2006; and many others). The social movements literature, of course, has long stressed the import of associations as an infrastructure for movements

\footnotetext{
${ }^{1}$ The aggregate prevalence of membership is correlated with the number of associations, but not as highly as one might expect. Some corporatist societies, for instance, generate very high levels of membership concentrated in relatively few associations.
} 
(McAdam, McCarthy, and Zald 1996). Sampson et al. (2005), for instance, show that neighborhood organizations powerfully influence protest and civic participation events, whereas more conventional measures of social capital (i.e., individual reciprocity ties) do not. Similarly, Baldassarri and Diani (2007) turn attention to associational life at the network level, documenting the interorganizational structure of "civic networks" in Glasgow and Bristol. And, more recently, social capital scholars have begun to look at how the scope of associational life at the aggregate level serves as an important antecedent to individual levels of trust and participation (Paxton 2007; Wollebæk and Strømsnes 2008). We have no stake in normative debates regarding the relative importance of membership versus association. Both phenomena are worthy of study, and we expand the literature through our attention to the latter.

\section{What are associations?}

We seek to characterize associational life, broadly defined, to understand the general social processes that lead to the crystallization of voluntaristic organization in the public sphere. We employ a conventional conceptualization of associations, drawing on Salamon and Anheier's (1996) work on the non-profit sector. Associations are organizations that are: (1) formal; (2) private - i.e., not part of the government (though they may receive government support); (3) non-commercial - i.e., not for-profit firms or private insurance or credit associations; (4) self-governing; and (5) voluntary. ${ }^{2}$ Furthermore, we apply three exclusionary criteria used by Salamon and Anheier: We

\footnotetext{
${ }^{2}$ Following Salamon and Anheier (1996), we do not require that an association must be entirely funded and supported by individual volunteers. Indeed, many associations rely exclusively on paid staff. Rather, some voluntary component is required (e.g., an independent voluntary board of directors).
} 
exclude (6) churches and religious schools $;^{3}(7)$ political parties (but not politically oriented organizations in general); and (8) labor unions. ${ }^{4}$ Finally, (9) we do not consider organizations structured around family or kinship (though associations representing ethnicities or other identities are included).

We employ an expansive definition, driven by the desire to understand societal voluntary capacity in the most general sense. Associations facilitate the provision of collective goods of the widest variety, provide the infrastructure for myriad social movements, and form the basis for pluralistic participation in governance in democratic societies and opposition in non-democratic ones. We seek to understand variability in this capacity across societies - and to understand some basic variations in its configuration. Associations are studied under many guises: non-profits, NGOs, civil society, voluntary associations, the 'third sector', etc. Each term has its own connotations, slightly distinctive definition, and in some cases implicit (or explicit) normative assumptions. While scholars expend a fair bit of effort debating the differences between these many terms, the substantive work overlaps a great deal, and we build upon that common ground (see Andrews and Edwards 2004).

As a practical matter, our data sources predominately capture larger associations that are active in the public sphere (see Data). In that sense, our work bears some similarity to Skocpol and Fiorina's (1999) study, which focused on groups that attained high levels of membership. Weakly organized, clandestine, or very small organizations tend to be poorly documented in our data sources. This limits our ability to generalize

\footnotetext{
${ }^{3}$ We do not exclude the vast numbers of service organizations, advocacy groups, and lobbying groups (e.g., the Salvation Army) that have religious content in addition to secular functions and activities.

${ }^{4}$ Labor unions are tightly embedded with the nation-state in some societies (e.g., Scandinavia). We wish to test arguments about the relationship between the state and private association, and therefore we err in the direction of excluding types of association that may be directly linked to the state in some contexts.
} 
about smaller or more reclusive associations, particularly to the extent that they are generated by different social processes than large, public associations (an open question). However, large and active associations are arguably the most consequential for many outcomes of interest to political sociologists - such as social movement mobilization, interest group representation, and social service provision - and thus warrant attention. These features of our dataset should be kept in mind when interpreting our results.

\section{Associations "From Society"}

A main theme of the literature is that associations spring up from society itself that is, from social interaction among individuals that possess appropriate attitudes, values, capacities, and resources (Putnam 1992, 2000; Almond and Verba 1963; Brady, Schlozman, and Verba 1995; see Orum 1989 for a review). The classic political participation literature emphasizes basic individual capacities and resources such as education, wealth, and leisure time (Almond and Verba 1963). Education generates awareness of and concern for collective problems and the skills to organize effectively, while resources and leisure time enable and sustain associational efforts (Almond and Verba 1963; Brady, Schlozman, and Verba 1995). Industrialization is thought to bring education and affluence which are necessary to support collective organizing, along with requisite "modern" or "postmaterialist" civic values (Inkeles and Smith 1976; Inglehart 1997). Thus, one would expect that: Societies with higher levels of education and wealth will have more associations.

\section{The State and Associational Life}


A large literature asserts the importance of political structures and institutions in shaping associational life (Paxton 2002; Skocpol and Fiorina 1999; Crowley and Skocpol 2001, 2003; Schofer and Gourinchas 2001; Clemens 1997; Tarrow 1998). Historical institutionalist approaches stress the ways that political and legal institutions form the landscape of resources, opportunities, and constraints that motivate, limit, or channel associational forms and political participation (Pierson 1993). Skocpol has done foundational work in this area showing, for instance, that the state influenced the form of U.S. voluntary associations (Skocpol, Ganz, and Munson 2000) and provided resources (e.g., Civil War pensions) and infrastructure that spurred civic life (Crowley and Skocpol 2001; also see Skocpol and Fiorina 1999; Clemens 1997). More recent cultural and neoinstitutional formulations have attended more directly to the institutionalized cultural scripts and schema which serve to constitute and legitimate collective actors, identities, and purposes (Schofer and Gourinchas 2001; Gourinchas and Schofer 2004).

The literature offers an extremely broad range of institutional factors that spur civic life, from general features of the state (e.g., democracy) to highly contingent events (e.g., the aftermath of the US civil war) to mundane infrastructures (e.g., postal systems). We distill this potpourri of arguments to theorize general features of modern political institutions that encourage associational life: (1) the expansion, in terms of size and scope, of state governance and (2) the openness or porousness of its political institutions.

State Expansion. We argue that the expansive size and scope of the modern state provides resources, legitimation, and identities that encourage and sustain associational life in modern societies, including but not limited to traditional interest groups. Modern 
states emerged as narrow extraction and warmaking enterprises (Tilly 1985, 1992) but expanded in size and scope across the $19^{\text {th }}$ and $20^{\text {th }}$ century to encompass the widest array of collective ventures, from sanitation to regulation of the economy to licensure of the modern professions to environmental protection. As the state expands, its reach brings new domains into the public sphere, serving to establish and legitimate them as foci of citizen and interest group involvement.

One might liken the expansion of state scope as a widening of the playing-field on which interest group and associational politics plays out. As a government begins to regulate the economy, for instance, a whole host of business interests and consumer groups have new and pressing raisons d'etre. Moreover, the broadening of state scope generates new categories, constituencies, and identities that become the building blocks of association. Tarrow's (1998) work on social movements outlines key dynamics:

State building not only made the national government a target for citizens' claims; it led to the broader cognitive and political framing of citizen actions. The standardization of taxation, of administrative regulations, and of census categories encouraged the formation of coalitions of groups that had previously been opposed or indifferent to one another. The classification of citizens into what started out as artificial groupings ... constructed new social identities or laid the bases for broader coalitions (Tarrow 1998:63).

Similarly, Skocpol remarks that the post World-War II rise of advocacy organizations in the U.S. is linked to the growing "range of national public undertakings" by the federal government (Skocpol 2003:200).

Our argument is also informed by scholarship on "policy feedback", in which features of the state and legal environment feedback into social and political life by providing incentives to key political actors and broader identities and meanings to mass publics (Pierson 1993). For example, Mettler (2002) found that the extension of social 
rights and educational provisions through the G.I. Bill had a positive effect on the political and civic engagement of returning veterans, especially those from more disadvantaged groups. Similarly, low-income seniors participate in Social Securityrelated political activities at higher rates than their incomes would suggest because of their dependence on the program (Campbell 2002). Much of the literature on policy feedback has focused on state actors and organized interests (Soss and Schram 2007), but we consider implications for associational life more broadly.

Consider U.S. environmental regulation. Efforts in the late 1960s and early 1970s to manage the natural environment (e.g., the formation of the Environmental Protection Agency and related legal frameworks) resulted in rapid proliferation of environmental interest groups (Caldwell 1990; Hironaka 2000; Longhofer and Schofer 2010). While some pro-environmental groups obviously preceded state involvement, the real explosion of environmental association occurred after the state moved into the domain. Expanded laws, regulation, and state intervention put the issue squarely on the public agenda and generated issues of contention around which industry and pro-environmental lobbyists, interest groups, and social movement organizations crystallized.

States also directly support and generate associations as they pursue expanded public agendas. A weak form can be seen in the non-profit laws in the United States, which provide favorable tax status and other incentives to encourage the formation of private associations. Direct government support for and collaboration with associations is more common in Europe and Asia. Scandinavian consociational democracy, for instance, involves large state subsidies for all sorts of associations. The expanding 
corporatist state in Sweden in the early part of the $20^{\text {th }}$ Century established formal channels for interest groups to participate in the political system. As Rothstein notes:

For example, the temperance movement was given the responsibility of handling the government's propaganda against widespread misuse of alcohol; the farmer's movement, the responsibility of handling subsidies to farming; small business organizations, the responsibility of implementing subsidies to support small business; and so on (Rothstein 2002: 214).

Collaboration between associations and the expanding state continued throughout the 1960s as the state promoted civic participation in areas like adult education, culture, and sports and recreation (Lundstrom and Wijkström 1997). Similarly, as Japan pursued its aggressive economic agenda in the post World War II era, the state supported and relied heavily on coordination among industry groups as part of attempts to manage the economy and generate economic growth. Corporate-sponsored foundations, which the government perceived as essential to Japan's modernization process, were given special tax treatments in the 1960s to foster donations and activities (Amenomori 1997:193). The result was a proliferation of industry and trade associations.

Thus, we expect: Societies with expanded states, in terms of size and scope, will have more associations than societies with smaller states.

We expect state expansion to have a positive effect on most forms of association. The state touches on nearly every part of the associational sphere, whether by providing licenses and monopolies to professional groups, serving as the target of social movements and industry associations, and even by defining and constituting sub-national groups and identities around which many community associations are formed. Nevertheless, some variation is likely. The examples above illustrate that Scandinavian welfare policies had a specific impact on social service organizations while Japanese industrial policy spurred 
the formation of commercial organizations and industry groups. We lack data to pursue the issue in our empirical study, but our argument logically suggests that substantive variation in government agendas may be mirrored in the associational sphere.

State Openness. A second general theme in the literature on voluntary association is the idea that some states are more congenial to associations, either because they are less repressive, less insular, or more explicitly inviting of participation by actors in civil society. The idea crops up in a variety of contexts: the literature on associations and democracy (e.g,. Paxton 2002), discussions of political opportunity structures and social movements (Meyer 2004), work on 'statism' (Schofer and Fourcade-Gourinchas 2001), and studies of civic life in Eastern Europe and the developing world that attend to the issue of state repression (e.g., Anheier and Salamon 1998). We focus on two expressions of state openness: democracy and decentralization.

Openness: Democracy. Democracy has received the lion's share of attention and is the main focus of our study due to the availability of high quality cross-national data. Tocqueville (2000[1835]), and many to follow, drew the link between the strong democratic institutions and traditions of the United States and its vibrant civic life (see Paxton 2002). Institutionalized political democracy opens the state to input and pressure from the outside, and thus provides strong incentives for citizens to mobilize and influence state decisionmaking. Skocpol (2003), for instance, argues that democratic elections and the build-up of mass political parties across the $19^{\text {th }}$ century supported rapid expansion in associational life. Moreover, democratic political culture provides powerful legitimation for individual participation in political life through forms that include (but 
are not limited to) voluntary association. In contrast, non-democratic societies routinely suppress or proscribe free association. The inability of citizens to influence a closed regime substantially reduces incentives to form interest groups and many other types of organizations. ${ }^{5}$ Indeed, these arguments are supported by prior cross-national research (Anheier and Salamon 1998; Paxton 2002; but see Ruiter and De Graaf 2006). We expect that democratic societies will have more associations than non-democratic societies.

Moreover, democracy should have an especially large positive effect on associations devoted to social or political issues and reforms. Non-democratic regimes place selective ecological pressures on associational populations because repression centers on those associations and movements that challenge the state or demand social reform, such as pro-democracy organizations or human rights groups. Associations that appear to be innocuous and/or apolitical (e.g., sports and recreational groups) are more likely to survive - and in some cases flourish - within non-democratic regimes.

Associational life in democratic societies will have a distinctive character, with more groups attending to social problems and political issues.

Openness: Decentralization. A second dimension of openness is the degree to which states are insulated from civil society pressures, versus being relatively porous or interpenetrated by societal actors. The issue is squarely addressed in comparative political work on statism and decentralization (Jepperson 2002). There is a substantial variability in associational life even among democracies, with famously porous states having the most and historically insular states like Japan and France exhibiting much lower levels of membership and association (Schofer and Fourcade-Gourinchas 2001).

\footnotetext{
${ }^{5}$ This is not to say that most or all association is directed toward the state, or that repressive societies do not also provide some motivations to form association (e.g., resistance groups).
} 
Decentralized states, such as the United States and Sweden, provide myriad structural opportunities for citizen influence, and typically exhibit a corresponding political culture that legitimates such participation. States with highly insular elite bureaucracies (France is the canonical example) provide few avenues for civil society influence, and repertoires of political participation tend not to emphasize membership and volunteering (Schofer and Fourcade-Gourinchas 2001). Thus, we expect that societies with porous decentralized states will have more association than those with insular 'statist' governmental institutions.

\section{World Society and Domestic Associational Life}

Neo-institutional scholars highlight a key dimension of globalization: the growth of trans-national organizations and culture (a "world society" or "world polity") in which nations are embedded (Meyer et al. 1997a; Boli and Thomas 1999). Institutions, culture, and discourses of world society have been shown to influence national policies and laws in areas such as education, women's rights, the environment, human rights, and so on (Ramirez et al. 1997; Frank et al. 2000; see Meyer et al. 1997a for a review). We argue that world society penetrates down into national societies, promoting and diffusing associational forms.

World society encourages domestic association in at least two ways. First, the globally legitimated issues and causes in world society extend down into national societies, bringing with them collective purposes, resource flows, and organizational models that encourage and empower domestic organizing (see Boli and Thomas 1999). In addition, "civil society" itself has become a celebrated myth in world society - a 
dominant and highly legitimated ideology. Key international actors have seized upon voluntary association as a panacea to a variety of social problems, leading to a further intensification of resources and energies devoted to domestic association.

\section{World Society as a Source of Legitimated Social Problems, Resources, and Models}

The world polity has dramatically expanded in the post-World War II era, with massive growth of international institutions and international non-governmental organizations (INGOs) on topics such as human rights, the environment, gender equality, AIDS, education, and so on (Boli and Thomas 1999). We argue that the expanding structure and scope of world society encourages association, analogous to our argument about the expanding scope of national states.

The legitimated global models and discourses of world society provide powerful cognitive frames for organizing and engaging in social movement activities (Benford and Snow 2000; Meyer et al. 1997b; Tsutsui 2008). International agreements and treaties encompassing a growing range of topics - define principles and legal standards and create global expectations of nation-state behavior and citizen action. At the same time, world society provides potent authoritative discourses, often purveyed by professionals, experts, and scientists, that identify and help to socially construct various issues and social problems (Drori et al. 2003; Schofer 1999; Haas 1992).

Entire packages of legitimated social problems, solutions, and social movement strategies get assembled in world society (often built upon movements that originated in Europe or the US), and can then diffuse to nations in every part of the world. In addition to defining social problems, international actors and social movements - such as 
Greenpeace and Amnesty International - generate innovative social movement frames that galvanize commitment and action (Wapner 1996). Once a social issue has been institutionalized at the global level, it becomes far easier for an individual anywhere in the world to take up the cause. This is very clear in the case of global environmentalism: international mobilization generated rapid changes in national environmental laws and sharp increases in domestic pro-environmental mobilization across the developing world (Longhofer and Schofer 2010; Frank et al 2007). ${ }^{6}$

Likewise, international non-governmental organizations (INGOs) frequently provide funds for local "capacity building" - which often takes the form of cultivating local associational infrastructure. Major global environmental associations, such as Friends of the Earth International, routinely support the formation of chapters - or wholly independent domestic associations - around the world (Wapner 1996). The period following the dissolution of the Soviet Union vividly demonstrates how resources pour into societies that are suddenly "opened up" to world society. As Russia transitioned from Soviet rule, international funding agencies, such as USAID and the MacArthur Foundation, funneled millions of dollars to Russian NGOs "specifically targeted toward constructing civil society" (Henderson 2002: 141).

Resources from world society can have a huge impact, particularly in the developing world where domestic resources are scarce. Survey data shows that over $70 \%$ of the aggregate funding for the Ugandan NGO sector comes from international NGOs and donors, and a good portion of the remainder comes from the state (which itself receives substantial international aid) (Barr, Fafchamps, and Owens 2005). Similar

\footnotetext{
${ }^{6}$ Indeed, one reason that the global movement was so successful in influencing national laws is that it simultaneously generated domestic pro-environmental constituencies - effectively "squeezing" the state from above and below at the same time (Schofer and Hironaka 2005).
} 
patterns have been documented in Thailand, where a large portion of funding comes from UN agencies (e.g., UNICEF, UNESCO, World Health Organization), and in Ghana, where foreign aid supported the growth of non-profit organizations during the military dictatorship of the 1980s (Pongsapich 1997; Uhlin 2002; Atingdui 1997).

\section{The Increasing Legitimacy of "Civil Society" in the World Society}

The notion of civil society, itself, has become a dominant and highly legitimated ideology in world society. Ushered in by decades of Anglo-American dominance and the neo-liberal turn, civil society has become a potent 'myth' and a taken-for-granted goal of intergovernmental organizations (the UN, World Bank, etc), international donors, and an array of INGOs (Das Gupta, Grandvoinnet, \& Romani 2003; Nelson 1995; Reimann 2006; Roßteutscher 2010). Civil society is now a celebrated cause and veritable panacea for nearly any social problem, ranging from ineffective democracy to environmental degradation to lagging economic development. This represents a sharp departure from an earlier view among the international development banks and donors, which saw the central state as the primary vehicle for solving social problems. Reimann has termed this phenomenon the "pro-NGO norm" that emerged in the international development field in the 1980s:

Based on liberal democratic and neoliberal economic principles, this new ideology supporting NGOs was one that included both service and advocacy NGOs and set up a new international standard for states. According to the new pro-NGO norm, in order to be a properly functioning free market and democratic nation in the 1990s and 2000s, it was now necessary to have a flourishing "civil society" sector that included NGOs and other citizen-organized groups (Reimann 2006: 59). 
The increasingly hegemonic pro-civil society discourse has lead to an intensification of the resources and organizational infrastructure devoted to supporting domestic association (Reimann 2006). Intergovernmental organizations (IGOs), including the UN and World Bank, directly encourage domestic association by providing resources, conferences, and training to individuals in developing countries. As Reimann notes:

UN support of NGOs since the 1980s has grown exponentially and now includes not only funding for implementation of UN projects but funding for attendance to UN conferences, NGO training and "capacity building" programs, and support for NGO networking. By the late 1990s, UN agencies were providing more than $\$ 2$ billion a year on NGO programs (Reimann 2006: 49).

The World Bank created a Civil Society Group in 1995, a collection of civil society "specialists" charged with coordinating capacity-building initiatives for civil society organizations and facilitating collaboration with domestic associations in Bank projects. $^{7}$ According to its website, the World Bank now contributes an estimated 10 percent of its annual funding portfolio (or \$2 billion) to civil society organizations and community-based initiatives, and, in 2009, more than 80 percent of all Bank projects included the active involvement of civil society organizations in their implementation (up from 20 percent in 1990). Such initiatives by the Bank involve not only the disbursement of funds directly to nongovernmental organizations, but also training programs, external consultations, and technical assistance from Bank staff to civil society organizations and governments (Siri 2002; Reimann 2006).

In short, the World Bank and many other international organizations have become engines of association. The ascendance of civil society as an ideology has also increased the legitimacy and standing of associations in global affairs. Private associations are

\footnotetext{
${ }^{7}$ Such efforts have been often criticized on the grounds that World Bank-supported NGOs may not result in true democratic representation of local groups. We certainly agree that internationally sponsored associations are likely to have different aims and agendas than those emerging from local societies.
} 
increasingly "brought to the table" or given consultative status within inter-governmental organizations. International conferences now provide space and voice for NGO representatives. There remains some doubt about their "real" influence, and NGO participation at times appears more ceremonial than substantive. Nevertheless, the increasingly legitimate status of civic associations vis a vis the international community serves as a huge incentive for groups to form associations.

Predictions. We begin with the conventional neoinstitutional prediction that linkage to world society matters: Nations strongly connected to world society will have higher levels of association. Conversely, societies that are less connected to world society either because they are intentionally autarkic (e.g., North Korea) or merely peripheral in the world organizational/cultural system - will have lower levels of association. Our arguments also suggest that transnational resources may play an important role in the formation of domestic association. We expect that nations receiving more resources from world society will have higher levels of association.

In addition to country-level differences in ties to world society, we argue that the historical structuration of world society at the global level encourages the proliferation of domestic association around the world. World society has become increasingly structured over time - with greater levels of informal and formal organizations, treaties, and institutions encompassing a wider scope of topics and issues (Meyer et al. 1997a). These historical trends intensify and broaden the influence of world society, independent of a country's degree of linkage. 
In addition, world society tends to encourage particular types of domestic association linked to globally legitimated issues: human rights, equality (e.g., gender issues, racial discrimination, democratic participation), social progress (e.g., economic development, educational expansion), and environmentalism (Boli and Thomas 1999; Boli 2005; Chabbott 1999; Frank et al. 2000; Thomas et al. 1987). Other topics, including religion and labor issues, are not strongly rooted in world society (Boli and Thomas 1999). A survey of Ugandan NGOs, for instance, finds that association and their activities "largely reflect the agenda and concerns of... international actors" (Barr, Fafchamps, and Owens 2005: 675). ${ }^{8}$ The agenda of world society is, thus, imprinted on domestic association. We expect: Nations strongly influenced by world society will have higher levels of associations devoted to social and political issues, such as human rights, development, gender equity, and the environment.

World society is also an extraordinarily rationalized domain, home to associations and extensive networks of professionals, experts, and scientists (Drori et al. 2003; Fourcade 2006; Boli and Thomas 1999). Studies have shown that the world polity which celebrates scientific rationality as a solution to many social problems - encourages the global proliferation of domestic scientific associations (Schofer 2003, 2004). We expect to observe a similar pattern for professional associations more broadly. Nations more strongly influenced by world society will have higher levels of professional and scientific associations.

\footnotetext{
${ }^{8}$ We do not mean to imply that these issues are not also pressing local needs. Rather, our point is that the organizational form, discourse, and agendas often have a lineage in global frames and discourses, rather than local or indigenous ones.
} 


\section{Data}

Measuring Associations Around the World

We collected longitudinal cross-national data on the prevalence of associations in the contemporary period. Our approach complements prior studies of individual association membership data from the World Values Survey (Andersen, Curtis, and Grabb 2006; Curtis, Baer, and Grabb 2001; Ruiter and De Graaf 2006; Schofer and Gourinchas 2001) and larger-sample studies that use international non-governmental organizations (INGOs) or their headquarters as a proxy for domestic associational life (Paxton 2002; Anheier et al. 2004; Kaldor et al. 2003). Our data provides a direct measure of association for a large sample of countries.

Our primary variables are derived from the Encyclopedia of Associations: International Organizations (the "EA") electronic database (Gale 2010). The phrase "international organizations" in the title is perhaps misleading, as it refers to domestic associations based outside the United States rather than associations that are literally international in scope or membership. The EA provides contact information and descriptions for associations and organizations as collected by Gale researchers.

The 2010 online edition of the international EA directory contains contact information for more than 32,000 membership organizations in over 200 countries. Examples include the German Mathematical Association, Family Planning Association of Kenya, and the Accordion Society of Australia. We coded each organization for country location, general subject area (based on a limited set of categories in the EA directory) and founding date. Our main analyses contain information on voluntary associations for 140 countries (some cases, especially tiny "microstates," are lost due to missing data on 
other variables). We constructed longitudinal data by drawing upon information on founding dates of associations to estimate the number in existence in prior years.

We made extensive efforts to assess the quality of our dataset and understand its limitations. 1) We provide a clear discussion of what our dataset includes and what is likely to be omitted. 2) We compare our EA data with other data sources, to determine the extent to which the EA has source-specific bias in measuring relative (if not absolute) differences in the prevalence of association across nations. 3) We address the "survivor bias" inherent in constructing longitudinal data based on a contemporary source, which necessarily omits associations that failed prior to the publication of our data source. What is Measured? Characteristics and Biases of Data from Organizational Directories. We argue that the EA provides a sociologically meaningful picture of the relative prevalence of voluntary associations in society and across time. The EA is not a complete census of all voluntary associations in the world. Rather, the Gale group relies on regional personnel around the world who conduct research and send out questionnaires in order to continuously expand their database. Organizational directories in general are known to be biased toward larger, more resource-rich, and more "mainstream" associations that are active in the public sphere (for instance, see Edwards and Andrews 2002; Brulle et al. 2007; Minkoff 2002). Directories undercount smaller and more radical associations, and typically provide no information on informal or clandestine groups. Brulle et al. (2007) also found that U.S. environmental organizations based in Washington, DC, were most likely to be listed in the national EA directory, and this likely applies to many other types of associations and across countries. However, 
they also note that the EA's likely strength is counting voluntary associations, which is the primary focus of our analysis.

The EA directory provides information on sociologically important types of association, but we cannot straightforwardly generalize to types of association that are underrepresented, particularly if they may arise from alternative causal processes. The bias toward larger and more resource-rich associations is most obvious. Our dataset is best able to measure large membership associations and politically active lobbying and advocacy groups, which tend to have large public profiles. This has great relevance for political sociologists interested in civic participation, social movements, and interest group politics. On the other hand, our dataset is less able to address local social capital of the sort that might be provided by small community groups or local bowling leagues. We discuss our findings with these issues in mind.

Finally, we focus on the overall count (i.e., density) of associations in society. Measures of budgets, membership, or level of activity are not systematically available. A great deal of research uses counts to measure the extent of organization - most notably organizational ecologists, but also scholars in political sociology, social movements, and organizational sociology generally - but it is important to acknowledge that simple counts do not directly measure all sociologically important features of associational life. Cross-National Source-Specific Bias. We collected data from several other sources to corroborate our EA data. These include data on national scientific and learned societies (Opitz 2002), national environmental organizations (Tryzna and Davidson 2001), headquarters of international non-governmental organizations (Union of International Associations 2001), and non-profit organizations registered with Action Without Borders 
through their Idealist website (www.idealist.org accessed March 11, 2005). We constructed an index by adding the z-scores of the natural log of each variable. The natural log of each variable correlated at .72 or higher with all other variables, and the final measure correlated at over .9 with the EA measure.

To the extent that sources have idiosyncratic biases (e.g., sources published in Anglophone countries might overcount Anglophone associations), we might expect low correlation across sources. In fact, we observe very high correlations, even among sources published in different countries (with different national languages). It is also reassuring that the EA source paints a very similar picture to specialized sources, which tend to be more comprehensive in their domain of coverage. For instance, the EA count of environmental associations in 2000 correlates at over .9 with national environmental organizations taken from an environmental directory (Tryzna and Davidson 2001). Again, this suggests that the EA directory does a good job of capturing relative differences in the level of association across societies. We principally focus on the EA data because it is available for a larger sample of countries, because it provides founding dates, and because the source can be disaggregated by type of association. Survivor Bias in Longitudinal Data. Longitudinal data on associations are constructed based on founding dates in our contemporary sources, and therefore may be subject to "survivor bias" whereby associations that have failed prior to the publication of our source are excluded from our data. The EA is not available at regular intervals far back in time and the quality in early years is poor, so we cannot remedy this issue. However, we replicate findings with cross-sectional data (not subject to such bias) and use an analysis restricted to the recent past to minimize such bias. Moreover, we provide 
multiple checks to assess the extent of bias and replicated our results using true longitudinal data on a more specific sample of associations. For instance, we compared our estimate of associations in 1991 with actual data from the 1991 volume of the EA. The correlation was roughly .8 - not perfect, but rather high. Second, we were able to pursue a direct check of the extent of bias for a subset of our organizational dataset. We found alternative sources to collect comprehensive historical data on one type of association: environmental groups. Again, we observed high correlations between our sources. More importantly, we found no substantial differences in regression results between the base (i.e., 'survivor biased') dataset and the comprehensive one. If anything, survivor bias weakened the findings rather than biasing them upward. This is reassuring, as we do not see evidence that the biases inherent in our data would lead to false conclusions.

\section{Dependent Variables}

We constructed five dependent variables from the EA data that measure both overall levels of association and the prevalence of specific types of organizations. Descriptive statistics can be found in Appendix A. Overall Association Level- Measured by taking the cumulative number of associations active each year based upon founding dates listed in EA for each country. We took the natural log of this variable to reduce skewness.

In addition to the overall association level, we disaggregated organizations into four subcategories based on subject area. Our disaggregation was limited by the categories used by the Gale organization, but nevertheless captures sociologically 
interesting subsets. For instance, the "social/political" category is useful for examining interest groups, advocacy groups, and movement organizations. Again, the natural logarithm of each variable was used to correct for skew:

Economic, Trade, and Industry Associations ("Trade”) - Associations include commercial organizations, trade groups, chambers of commerce, tourism associations, and agriculture and commodity exchanges. Examples include the Indonesian Nutmeg Exporters Association, Zimbabwe Butchers Association, and the Tokyo Trade and Industry Association.

Social, Political, and Welfare-Based Associations ("Social/Political") - These associations are typically devoted more to broader collective goods rather than the interests of their membership bases, such as community development, welfare, public affairs, human rights, public health, and environmental protection. Examples include the Environment and Development Association of Ghana, Brazilian Interdisciplinary AIDS Association, and the British Institute of Human Rights.

Professional, Educational, and Scientific Associations ("Professional”) - These associations typically advocate on behalf of scientific professions and vocations, such as natural and social science organizations, educational associations, and organizations by profession. Examples include the Israel Society of Aeronautics and Astronautics, Russian Society of Sociologists, and Argentine Association of Dermatology. Recreational and Cultural Associations ("Cultural”) - Finally, recreational and cultural associations comprise ethnic and national cultural groups, arts organizations, hobby associations, and a host of athletic organizations. Examples include Bermuda Society of 
Arts, Elvis Presley Fan Club of Luxembourg, and the Women's Soccer Association of New Zealand.

\section{Independent Variables}

We examine a series of country-level factors that may explain variation in both the size and composition of associational life. A summary of variable descriptions is provided in Appendix B.

National wealth- We measure national wealth by gross domestic product (GDP) per capita (logged, World Bank 2010).

Education- Education is measured in a conventional manner, as the gross enrollment ratio in secondary educational institutions (World Bank 2010). ${ }^{9}$ We divided the measure by 100 to aid in interpretation.

Democracy- Measured as a fourteen-point scale reflecting the level of civil liberties and political freedoms in a country (Freedom House 2009).

State expansion. We measure state expansion based on both the fiscal activities and overall structure of the state. An index was constructed by adding the z-scores of three variables: government expenditures as percentage of GDP (logged; World Bank 2010); social transfers as percent of GDP (logged; World Bank 2010); and legislative effectiveness (Banks 2008). Government expenditures and social transfers are strongly associated with the historical expansion of the modern state and reflect the size of the state in the broadest sense. However, to account for the structural expansion of the state, and its ability of the central government to take on new agendas, legislative effectiveness

\footnotetext{
${ }^{9}$ Percent enrolled in tertiary educational institutions yielded similar results, although the sample size dropped due to missing data so we excluded the variable in analyses presented below.
} 
is used. We also corroborated our results using a more comprehensive measure (which is unfortunately available only for a smaller sample and for fewer years) created by Hironaka (2005) which is based on five indicators of state expansion: government expenditures per capita, logged (World Bank 2010), government expenditures as percent of GDP, logged (World Bank 2010), state scope (Gurr 1989), overall legislative effectiveness (Jaggers and Gurr 1996), and railroad mileage as measured per square mile, logged (Banks 2008).

Although we are primarily interested in democracy and state expansion, we also consider two additional measures of state structure:

State expansion interacted with democracy: We include an interaction term of democracy and a mean-centered version of state expansion to assess whether the effect of an expansive state is conditional on a country's level of democracy. Decentralization: We expect that decentralized, or nonstatist, political institutions encourage voluntary associations. We construct an index of three variables: Schneider's (2003) measure of fiscal decentralization; Gerring and Thacker's index of federalism (2004); and Jepperson's measure of decentralization vs. statism (recoded, high $=$ more decentralized) (Schofer and Fourcade Gourinchas 2001). This variable is not timevarying (in contrast to all others in our analyses). State decentralization does not change rapidly over time, and so available sources treat it as a constant property of states.

We consider several measures that reflect organizational and resource links to the world polity as well as its structuration over time, including:

World society linkages: Our primary measure of world polity linkages is citizen ties to international non-governmental organizations (INGOs) (Boli and Thomas 1999). The 
variable, which reflects cross-national variation in nation embeddedness in world society, is measured by the number of individual INGO memberships held by citizens in a country, logged (UIA, various years; see Schofer 2003; Frank et al. 2000). This is the most common way to assess which nations are most affected by the world polity, in large part because of Boli and Thomas's (1999) work, which stresses the importance of INGOs as carriers of world cultural models and discourse. These models, we argue, provide cognitive frames and help define the social problems around which many domestic associations organize.

World society structuration: In addition to an individual country's ties to the world society via national-level memberships in INGOs, we also measure the historical structuration of the world polity as the natural log of all international non-governmental organizations operating at the world-level as a time-varying, though not country-varying, variable.

World Bank “civil society” projects: To measure the effect of the World Bank on the funding and formation of associations, we recorded the cumulative number of development projects funded by the Bank with a stated purpose of fostering civic engagement. Data were taken from the searchable Projects and Operations database at the World Bank's website (www.worldbank.org). We searched for all projects with a "theme" of civic engagement (all Bank projects are labeled by themes, though the actual projects may vary in terms of size and/or industry sector). We use the natural log to account for skew. This measure captures national linkage to world polity resources, and also reflects the growing institutionalization of pro-NGO policies and discourses in the world polity. 
Official aid and development assistance: Finally, we include official development assistance (as a percent of GDP) as an additional measure of world polity influence (World Bank 2010).

In addition to the independent variables described above, we also include the following control variables. To account for more associations among more populated areas, we control for total population (logged, World Bank 2010). Also, we control for political instability, using Arthur Banks' (2008) weighted index of assassinations, strikes, guerrilla warfare, government crises, purges, riots, revolutions, and anti-government demonstrations (divided by 100 and logged). Finally, we control for civil wars with a dummy variable for years of ongoing war (Sarkees 2000). We include these variables to control for civil strife, which may weaken the capacity for a society to support an active associational life. We conduct two-tailed tests, however, as Skocpol has argued that the American civil war generated forms of national mobilization that encouraged civic association.

We also examined a variety of alternate model specifications, including variables such as postmaterialist values, foreign investment, statism, corporateness, internet hosts, televisions per capita, world-system position, regional dummies, urbanization, colonial history, and Protestantism. Our main findings were unaffected by these variations in model specification (unless sample size shrank dramatically due to missing data or several highly correlated variables were included at the same time). 


\section{Methods}

We use panel regression models to study the density of associations in countries from 1970 to 2006 (see Baltagi 2008; Wooldridge 2002; Halaby 2004). ${ }^{10}$ Pooling data over time data can yield improved estimates by drawing on temporal variability in data, and allows models that address unobserved heterogeneity, effectively eliminating country-specific, time invariant omitted variable bias. However, pooling results in nonindependence of cases that represent the same country at different points in time. One common strategy to address this issue is a panel model with fixed effects:

$$
\begin{aligned}
& \text { ASSOCIATIONS }_{i t}=\beta_{1} \text { WEALTH }_{i t}+\beta_{2} \text { POPULATION }_{i t}+\beta_{3} \text { EDUCATION }_{i t}+ \\
& \beta_{4} \text { CIVIL_WAR }_{i t}+\beta_{5} \text { POLITICAL_INSTABILITY }_{\text {it }}+\beta_{6} \text { DEMOCRACY }_{\text {it }}+ \\
& \beta_{7} \text { STATE_EXPANSION }_{i t}+\beta_{9} \text { WORLD_SOCIETY }_{i t}+\alpha_{i}+\varepsilon_{i t}
\end{aligned}
$$

where countries are indexed by $i$, years are indexed by $t$, and $\alpha_{\mathrm{i}}$ specifies a distinct intercept for each country that captures "unobserved" (time-invariant) features of each case. ${ }^{11}$ In effect, the model discards cross-national variation and exploits only "withincase" variability over time. This fixed effects approach is less efficient than a random intercept model ("random effects"), but avoids the strong assumption that there is no relationship between $\alpha_{i}$ and the independent variables in the equation. A Hausman test is generally used to adjudicate between fixed and random effects (Wooldridge 2002; Halaby 2004). In our case, Hausman test results varied across our analyses. Rather than

\footnotetext{
${ }^{10}$ Given roughly 36 years of data, one might argue that "Time-Series Cross-Section" (TSCS) models are more appropriate than conventional panel models (Beck and Katz 2009). We replicated our key findings (e.g., Table 1, Model 3) using OLS regression and "panel corrected" standard errors (not presented here; available upon request). Results were consistent.

${ }^{11}$ Independent variables are measured contemporaneously in static models, as is most common in the econometrics literature. However, lagging X variables does not alter our results (not presented here; available from the authors).
} 
presenting a mix of random and fixed effects models, we opted for a conservative approach that also simplifies presentation: we use fixed effects models throughout.

Beyond the conventional regression assumptions, fixed effects panel models assume that errors are "strictly exogenous" of independent variables - not just exogenous in any given year, but also with respect to the past and future (Wooldridge 2004). While there is no exhaustive test to rule out violations of strict exogeneity, we examined model specifications that address obvious forms of omitted variable bias and endogeneity, including dynamic models. We further consider models that relax the strict exogeneity assumption, below. Efficient estimation and accurate standard errors also depend on the assumptions that errors have constant variance across time and are serially uncorrelated (conditional on $\alpha_{i}$ and $\mathrm{X}$ variables). Serial correlation can be difficult to diagnose in unbalanced panel models (Wooldridge 2004:274). Dynamic models (see below) are one useful strategy, as the lagged dependent variable absorbs much or all of the correlation over time. We also replicated our main findings using robust variance estimators that are less sensitive to violations of these assumptions. However, robust standard errors presume small-T/large $\mathrm{N}$ asymptotics and may not be appropriate with our sample of about 36 waves of data and 140 countries (Wooldridge 2004). Finally, Allison (2009) outlines a strategy to overcome a key limitation of fixed effects models: the inability to include time-invariant variables. This proves useful in Table 3, Model 8 where we wish to examine a time invariant variable. ${ }^{12}$

\footnotetext{
${ }^{12}$ Specifically, one estimates fixed effects coefficients using a GLS or MLE random effects estimator, by manually generating group-mean and group-mean-centered variables to separately model "between" group and "within" group variation. The model generates identical estimates to a fixed effects model using GLS estimation, but also allows the inclusion of additional time-invariant variables, which is not possible using Equation 1.
} 
We also consider dynamic panel models, which include one or more lagged values of the dependent variable $\left(\mathrm{Y}_{\mathrm{it}-\mathrm{n}}\right)$ as independent variables. We present results based on a 5-year lag (one-year and ten-year lags yielded similar results). Dynamic models may be advantageous for two reasons. Most obviously, they are appropriate for processes theorized to be highly dynamic (e.g,. if recent trends in Y powerfully feed back into current values of $Y$ ). Second, by controlling for recent values of $Y$, one may reduce or eliminate some forms of serial correlation and endogeneity. For instance, omitted variables that influenced $\mathrm{Y}$ in the past can be "netted out" in a model that controls for recent lags of $\mathrm{Y}$ - in effect, focusing on $\mathrm{Y}$ relative to a recent historical baseline. The inclusion of the lagged dependent variable violates the strict exogeneity assumption of a fixed effects model, but the resulting bias diminishes with $\mathrm{T}$ (the number of waves of data) and eventually becomes inconsequential as $\mathrm{T}$ reaches thirty (Nickell 1982). With over thirty-five waves of data, our study is not affected by this potential source of bias.

We further examine models robust to violations of strict exogeneity, which may result from potential non-recursive relationships among variables. We consider three possible reverse-causal dynamics, where our dependent variable may influence independent variables: associations may affect democracy (see Paxton 2002), the expansion of the state, and national linkages to world society. A common strategy in the econometrics literature is to use one or more lagged values of independent variables (which are arguably exogenous to variables measure later in time) as instrumental variables for estimating causal effects (Wooldridge 2002; Baltagi 2009). The conventional two-stage least squares (2SLS) panel data system of equations is as follows: 


$$
\begin{aligned}
& \text { ASSOCIATIONS }_{\mathrm{it}}=\beta_{1} \text { DEMOCRACY }_{\mathrm{it}}+\beta_{2} \text { STATE_EXPANSION }_{\mathrm{it}}+ \\
& \beta_{3} \text { WORLD_SOCIETY }_{\mathrm{it}}+\beta_{\mathrm{k}} \mathrm{X}_{\mathrm{it}}+\alpha_{\mathrm{i}}+\varepsilon_{\mathrm{it}} \\
& \text { DEMOCRACY }_{\mathrm{it}}=\gamma \text { DEMOCRACY }_{\mathrm{it}-\mathrm{n}}+\gamma_{\mathrm{k}} \mathrm{Z}_{\mathrm{it}}+\xi_{\mathrm{it}}
\end{aligned}
$$

$$
\text { STATE_EXPANSION }{ }_{i t}=\gamma \text { STATE_EXPANSION }_{\mathrm{it}-\mathrm{n}}+\gamma_{\mathrm{k}} Z_{\mathrm{it}}+\xi_{\mathrm{it}}
$$

$$
\text { WORLD_SOCIETY }_{\mathrm{it}}=\text { WORLD_SOCIETY } \mathrm{it}_{\mathrm{it}}+\gamma_{\mathrm{k}} \mathrm{Z}_{\mathrm{it}}+\xi_{\mathrm{it}}
$$

where $\beta \mathrm{X}$ and $\gamma \mathrm{Z}$ represents other exogenous covariates and $n$ refers to some lag period to ensure exogeneity.

We employ the "system GMM" instrumental variable panel estimator, which is more efficient than the 2SLS estimator (Arellano and Bover 1995; Blundell and Bond 1998). This Generalized Method of Moments (GMM) estimator builds on equations 2-5 but employs first-differencing to eliminate unobserved heterogeneity, incorporates multiple lags of endogenous variables as instruments (rather than just one lag) in Eqs 3-5, and further improves efficiency by specifying parallel equations in levels in which multiple lags of first-differenced variables are used as instruments (see Wooldridge 2002; Baltagi 2009). The latter step yields an expanded system of equations - hence the name “system GMM". Models below utilize lags from two to five years, inclusive, as instruments in the first-differences equation and all available lags of endogenous measures in the levels equation. All exogenous $\mathrm{X}$ variables are also included.

Instrumental variables models assume the instruments are correlated with the endogenous explanatory variable and uncorrelated with the error term. The former can be straightforwardly assessed and is not an issue. The latter is typically examined via a Sargan test of overidentifying restrictions. In addition, the system-GMM estimator assumes the absence of serial correlation beyond first-order, which is evaluated via an 
Arellano-Bond test of serial correlation. Diagnostics did not identify violations of these assumptions. The system-GMM has mainly been employed in "small T" contexts, whereas our main analyses involve a moderate $\mathrm{T}$ of 36 waves. We replicated our findings on a subset of our data (taken at 5-year intervals) to ensure that the results are consistent when $\mathrm{T}$ is small (see Table 2). Finally, we note that nearly identical results can be obtained using traditional 2SLS instrumental variables panel estimators; our findings do not hinge upon the use of the system-GMM estimator.

Finally, we examined diagnostics for multicollinearity and influential cases. Partial regression plots and DFBETAs identified the following outliers, which were excluded from all analyses: Rwanda from 1994-2006 (during and after the genocide); Latvia in 1992 (the first data point available following the collapse of the USSR); The Gambia from 1984-1994 (roughly corresponding to a period of instability); and Argentina from 1970-1978 (a period of instability). Also, Saudi Arabia was identified as outlier in dynamic models (e.g., Table 1, Model 4).

\section{Results}

Descriptive Patterns Around the Globe

We begin by describing the topography of association through a pair of descriptive maps. Figure 1 maps association density within countries after adjusting for population. As one might expect, associations are highly concentrated in the affluent democracies of North America, Western Europe, and Scandinavia, as well as Japan and Australia. Densities tend to be lower in other regions of the world, but there is a great deal of heterogeneity. In sub-Saharan Africa, associations are sparse except in the 
southern region (i.e., South Africa, Botswana). In South and Southeast Asia, associations are denser in Malaysia, the Philippines, and Thailand. Finally, association levels are relatively high in Latin America as a whole, and particularly in Chile, Argentina, and parts of Central America.

A more complex picture emerges when looking at relative changes in association density. Figure 2 maps percent change in association density for 1991-2006. We focus on the latter part of our analysis period in order to incorporate data from the former Soviet republics and newly-independent Eastern European countries. A number of striking patterns emerge. Growth rates are moderate in many of the industrialized democracies with North America and Western Europe showing continued steady expansion. Yet, the most rapid growth is found elsewhere. The most active regions are Eastern Europe and Central Asia. ${ }^{13}$ This is consistent with our arguments: following the demise of the Soviet Union, much of the region experienced democratization and rapid penetration by global influences (including international NGOs and foreign aid). Latin America, which had fairly high levels of association to begin with, experiences slow growth after 1990. It is worth noting, however, that Latin America saw rapid growth in associations during the democratization periods of the 1970 s and 1980s. ${ }^{14}$ Thus, our focus on the post-1990 period in Figure 2 understates the extent of change in Latin America.

In sum, associations are most common in wealthier democracies, but many parts of the world have experienced significant rates of growth in the recent period. At first

\footnotetext{
${ }^{13}$ Our main statistical results, below, are not purely the result of rapid growth in Eastern Europe and Central Asia. We observe similar results when those cases are excluded from our analyses.

${ }^{14}$ On average, associations grew by 65\% in Latin American countries between 1975 and 1990, compared to only $26 \%$ between 1991 and 2006.
} 
glance, the growth of association appears to map onto regions of rapid democratization and increased connections to world society. We now turn to our statistical analyses, to identify the factors most strongly associated with such changes.

\section{Levels of Association}

Table 1 presents fixed effects panel models predicting the overall level of association in 140 countries from 1970 to 2006. Model 1 includes the measures for wealth and education, as well as controls for population, civil war, and political strife. As expected, we find positive effects for wealth and education, consistent with classic political sociology arguments. Civil wars do not have a significant effect on associations (although it is in the expected direction), but political instability actually has a positive and significant effect. The finding, which recurs in subsequent models, was unexpected but does make some sense. Simmons (2009) argues that countries undergoing moments of democratic transitions and political unrest experience greater amounts of social movement activity due to a heightened sense of collective efficacy among movement leaders and participants. This may also encourage the formation of associations. For instance, associations grew rapidly in the newly democratizing countries of Eastern Europe and Central Asia, which experienced a fair amount of civil unrest. Finally, population has a large and highly significant effect on associations. This effect is consistent across Tables 1-4 (for brevity, we discuss it no further). ${ }^{15}$

\footnotetext{
${ }^{15}$ Robust standard errors, which assume "small-T/large-N" asymptotics, may not be appropriate for our dataset of 36 years and 140 countries. Nevertheless, we examined them and noted some differences in results: education and political instability fall just shy of significance in Model 1, and education occasionally fails to be significant in other models. Also, democracy has a non-significant effect on trade and professional organizations (Table 5). Results available upon request.
} 
Model 2 includes the measures for democracy (one dimension of openness) and state expansion. Democracy has a positive and significant effect, consistent with work by Paxton (2002). The state expansion index also has a positive and significant effect, with a coefficient of nearly .03 . Given the log scale of the outcome variable, a percentage change interpretation applies: each unit change in the state index yields roughly a 3\% increase in associations. This finding lends support to our argument that expanded states support higher levels of associational activity.

Model 3 adds a standard measure of world society linkage, national-level memberships in international non-governmental organizations (INGOs). World society linkage has a positive and significant effect on domestic association. A ten percent increase in INGO memberships, a typical annual change, is associated with a $2.6 \%$ increase in our dependent variable. This supports our argument that world society supports domestic association. Interestingly, the coefficient of national wealth tends to shrink when INGO memberships are included.

As a check on the robustness of our findings, we also present a dynamic fixed effects model with a lagged dependent variable (Model 4). When controlling for the previous level of associations within a country, we still find positive effects of democracy, education, state expansion, and world society linkages, although the effect sizes shrink in some cases. By controlling for recent values of the dependent variable, we explicitly model dynamic processes and also may help capture the effects of other omitted variables (beyond those addressed by the fixed effect). As is often the case, coefficient sizes are substantially smaller in dynamic models. After controlling for recent values of the dependent variable, there is often little variability left to explain (Plumper, Troeger, and 
Manow 2005). We also find that national wealth actually has a negative effect on association levels in the dynamic model. This suggests that wealthier countries experience lower levels of association growth over time, which was also evident in our descriptive observations. In short, dynamic models are a conservative test and we are reassured by the fact that most results remain consistent.

Table 2 presents two instrumental variable panel models with system GMM estimation as an additional check on the robustness of our findings. Three independent variables - democracy, state expansion, and world society linkages - are treated as potentially endogenous. Lagged values of those variables, which are historically prior and thus less plausibly influenced by contemporary values of the dependent variable, are used as instrumental variables to estimate effects (see Methods). Again, key findings hold up. Coefficient sizes in Model 5 are generally similar to Table 1. Model 6 replicates the previous model but includes only data for five-year intervals (1970-2005), to reduce the number of waves in our data $(\mathrm{T})$. The GMM estimator was designed for "small T" and its properties for "large T" are not well understood. Results in Model 6 are similar, though the coefficients for state expansion and world society linkages are substantially larger (we have no explanation for the difference). Both GMM models show that democracy, state expansion, and world society linkages all have has a positive effect on association. We also see positive and significant effects of economic wealth, education, and political instability in these models.

\section{Additional State Effects}


We consider additional effects of state expansion and openness in Table 3. First, we examine the interaction of democracy and state expansion (Model 7). Expanded democratic states certainly encourage association, but large autocratic ones (e.g., the former Soviet Union) may not have a similar effect. ${ }^{16}$ Indeed, we observe that the effect of an expansive state on associational life is conditional on its level of democracy: we find a positive interaction between state expansion and democracy. However, the large main effect indicates that state expansion is important for association even in undemocratic societies.

We present a measure of decentralization in Model 8, another indication of state openness. We find that decentralization has a positive and significant effect on the density of associations in society. Decentralization of state authority (as opposed to its concentration within an elite bureaucracy) encourages association, consistent with individual-level studies of membership (Schofer and Fourcade Gourinchas 2001).

\section{Additional World Society Effects}

Table 4 further explores the impact of world society on domestic association. Model 9 looks at world society structuration, a measure of the historical expansion of organization and activity at the global level. As world society expands, it provides increasing support and legitimation for local association, potentially even affecting all nations (irrespective of a particular country's linkages to world society). Indeed, we find a positive and significant effect of world society structuration on domestic association.

In addition to our general measure of organizational linkage to world society, we consider more specific measures of resources - foreign aid - which may encourage

\footnotetext{
${ }^{16}$ We thank Doug McAdam for this suggestion.
} 
domestic association. Samples are limited to less-developed aid-receiving countries. Model 10 examines the effect of official development assistance from bilateral aid agencies, which may provide financial resources for new associations, particularly those involved in the implementation of development-related projects. We do find a small yet significant effect of aid on associational density in these countries.

A perhaps more interesting picture emerges when we look at development lending from multilateral agencies and, more specifically, the World Bank. As discussed above, development agencies like the World Bank have increasingly relied upon consultations with civil society organizations when implementing projects, oftentimes funneling resources to them in the process. In addition, the World Bank has expanded its lending programs to include projects with the explicit focus of empowering civil society. To test whether this shift in lending has fueled domestic association, we include a measure of all civic engagement-themed projects funded by the World Bank (for countries eligible for World Bank assistance). The effect of World Bank civil society project funding is positive and significant. In short, a variety of world society measures appear to encourage voluntary association around the globe.

\section{Types of Association}

Table 5 turns to disaggregated analyses of different types of association. Again, we use fixed effects models, though findings are results are robust when using alternatives (as in the sensitivity tests in Table 2). We find that national wealth is significantly associated with trade and professional associations, and its coefficient is substantially larger than on social/political and cultural associations. Although we did not 
specifically predict this, it makes a great deal of sense, as trade federations, industry groups, and professional associations are likely to accompany the industries on which they are based.

Education has a positive effect on all forms of association, though the effect varies substantially in size. Education has a particularly large effect on professional and scientific associations, consistent with the idea that education is the basis for the professions and sciences in the modern world. We also find large, significant effects of education on recreational/cultural associations. To our surprise, education has the smallest effect on social and political issue associations. Perhaps mobilization around political issues is shaped principally by the state itself (as well as world society; see below) and therefore is less directly dependent on the political skills of citizens.

State expansion has a positive significant effect on social and political organizations and trade/industry groups. The state, as it expands historically to address an increasingly wide range of economic, political, and social issues, offers broad incentives for association in those areas. In addition, state expansion has a positive and significant effect on scientific and professional groups, which makes sense in light of the state's historical role in supporting higher education and science, as well as the state's role in professional licensure. Finally, the expansion of the state has little impact on recreational and cultural activities, as indicated by a very small and statistically insignificant coefficient. This non-effect shows that the impact of state on civic life is not universal but rather is directly linked to the substantive areas in which the state operates.

Democracy also has a large and significant effect on social and political issue associations, as one would expect. Those are the sorts of associations that are most likely 
to be suppressed by non-democratic regimes. In contrast, democracy has a positive but smaller effect on trade associations and professional associations, and no significant effect on recreational/cultural associations. In other words, autocratic regimes do not significantly dampen recreational groups (e.g., chess clubs and sporting leagues). This supports our expectation that repressive states are most likely to suppress associations that challenge state authority, such as autonomous political groups, but may tolerate less explicitly political forms of association. Thus, democratic societies are distinguished by their very high levels of social/political associations and, to a lesser degree, trade and professional associations.

World society linkages (INGO memberships) have a consistent positive and significant effect on all types of domestic association. However, the magnitude varies quite a bit. World society has the largest effect on social/political issue associations, lending support to our expectation that the world polity disproportionately sponsors associations that address globally legitimated social issues, such as development and the environment. World society linkages also have a positive, though not as large, effect on professional and scientific associations. We thus find support for our argument that a highly rationalized world society encourages the diffusion of professional and scientific organizations. We also find a positive effect of world society on trade and cultural/recreational associations, which we did not predict a priori. The world society literature has focused relatively little on trade/industry activity in the international sphere, but even a brief glance at data sources (such as the Yearbook of International Organizations) shows tremendous expansion over time. The same is true of recreational 
groups. In short: it is plausible that world society would affect domestic association in these areas. Further scholarship on these dimensions of world society is warranted.

\section{Discussion}

Levels of Association. Much scholarship on civil society emphasizes individuals - and their skills and resources - as the origin of associational life. We find support for this view. Aggregate measures of education and national wealth tend to have positive effects on the number of associations in society in most models. ${ }^{17}$

Our findings put a spotlight on structural factors deriving from the broader national and global polities, particularly the openness and expansion of the state, and the influence of an increasingly structured world society. Taken as a whole, the state-level variables account for a major share of variation in associational life. Large, open states preside over the most vibrant civil societies in the world, while small autocratic regimes generate very little association. Linkages to world society and world society structuration over time also serve as a major impetus for voluntary organizing. Moreover, resources from the international community (here measured by aid and World Bank lending) have a direct impact on association in the developing world.

Types of Association. As we predicted, democracy has a positive and significant effect on social/political associations. Democratic societies tilt the associational sphere of a society toward social/political issue associations and away from other types of association in a relative sense. Or, perhaps more intuitively, autocratic societies tilt

\footnotetext{
${ }^{17}$ One exception: the effect of wealth flips to negative in dynamic panel models. This could reflect the slowing of association growth in wealthy countries (see Figures $1 \& 2$ ); or it may be an artifact of the fairly conservative nature of dynamic fixed-effects models, which purge the model of much real variance potentially throwing the "baby out with the bathwater" (Plumper, Troeger, and Manow 2005).
} 
associations away from social and political issues. Education, in contrast, has a smaller effect on political and social issue organizations, but does strongly affect the levels of recreational/cultural associations and the professions. ${ }^{18}$ Our analyses also suggest that the state generates high levels of economic, trade, and industry associations, as well as professional and social/political associations. Finally, we find that world society encourages association of all types, but that the social issues that are so much the focus of international organizations and institutions - such as human rights, women's issues, environmental issues, and development - are most strongly reflected in social/political issue associations at the national level. In a sense, world society imprints a mirror image of itself on domestic society.

Configurations of Civil Society. We have identified factors that shape the level and type of association in society. But, what are the holistic consequences? What kinds of civil societies are produced? We briefly describe several cases to exemplify common patterns and to provide a sense of the varied configurations that can emerge: ${ }^{19}$

1. "Classic" civil society. Sweden proves exemplary of the industrialized Western nations, which have extremely high levels of association and roughly equal representation across the four types in our study (trade/industry, professional, social/political, and cultural/recreational). The highly educated, democratic societies and expanded states found in the industrialized West are home to the largest - and most diverse - civil

\footnotetext{
${ }^{18}$ Given the rooting of the modern professions in schooling, the latter finding makes a great deal of sense.

${ }^{19} \mathrm{We}$ put forth these four categories as illustrations of the diversity of associational life, rather than as a formal typology. A rigorous and systematic treatment of civil society morphology warrants another paper. However, we should note that these four categories are crudely distinguishable via exploratory factor analysis. Specifically, we analyzed the proportion of a nation's associations that fall in each of our four types. Plots of national factor scores generate observable (but somewhat messy) clusters that broadly map onto the four categories discussed below. Analyses are available from the authors upon request.
} 
societies in the world. Associations of all types abound, addressing the many legitimate issues of the public sphere, and also emerging around the social, cultural, and recreational activities of citizens. In short, Sweden and many other countries of the industrialized West conform to the classic notion of civil society developed in the extant literature. There is, of course, variation within these cases. For instance, liberal/decentralized and corporatist polities are distinctive (Schofer and Fourcade-Gourinchas 2001), but in a global comparison they nevertheless appear quite similar.

2. State-Driven Civil Society. We find that the scope and openness of the state encourages associations of various types, but one can imagine instances of the state encouraging the formation of associations along certain trajectories. One instructive example is the case of Korea, which reflects a pattern common to many newlyindustrializing Asian nations: moderate-to-low levels of association overall, roughly half of which are trade and industry groups. The strong, development-centric states of industrializing Asian economies appear to have generated a unique variant of associational life. Lacking a long history of democratic traditions or highly-expanded European-style welfare states, association expands around the main legitimate activity in the public sphere; in the case of Korea, it is economic development, but one can imagine civil societies oriented round other state-led initiatives, such as welfare or public health. 3. Exogenous (Development-Centric) Civil Society. In Tanzania, like many other developing nations, the associational sphere is dominated by social/political issue associations, which comprise roughly half of all associations. Many associations are devoted to development, specifically, or a host of related themes, including public health (esp. AIDS), women's rights, environmental sustainability, and the like. In the absence 
of a highly educated population or expanded state, exogenous influences and resources become a major factor in encouraging and shaping associational life. Civil society is in large part derived from and dependent on the cultural models and resources of world society, which emphasize issues such as development, human rights, and the environment (also see Howell and Pearce 2001; Henderson 2002; Barr, Farchamps, and Owens 2005). As a consequence, the proportion of social and political issue associations in low income countries is far greater than in the developed world. Other forms - trade/industry associations, professional groups, and recreational/cultural associations - are proportionally less common, especially the latter.

4. Repressed Societies. Countries such as Syria and North Korea have very few civic groups, even compared to impoverished Sub-Saharan countries. Societies with a long history of government restriction and repression tend to have very little associational activity across the board, and particularly in areas relating to governance and the public sphere. The former Soviet republics also serve as examples, although they have changed dramatically since 1991. In our dataset, highly democratic societies have on average 23 times the number of total associations than the most repressive in the world (e.g., Syria).

This exercise in inductive description - as oversimplified as it is - provides the reader with some sense of how different countries are in terms of their associational spheres. It is often assumed that all voluntary associations are essentially the same around the world and will yield common benefits. For instance, the notion that associations represent a "third sector" that balances against the power of the state is a recurring theme - but it may not generalize, for instance, to societies in which the bulk of associations are built around state goals related to economic development. Recognizing 
these holistic differences in associational life, thus, provides a basis for making predictions about the large-scale impact of associations on society.

\section{Conclusion}

We seek to understand the origins of voluntary association in the broadest sense and its variation around the globe. We observe that associations arise from society (affluent and educated citizens), from an open and expanded state, and from an increasingly structured world society that is ever more densely connected to nations.

The importance of education and wealth are no surprise, and prior work has suggested the importance of democracy. We emphasize the expansive scope and openness of the modern state and the rapidly expanding world society as powerful sources of association. The growth of macro-institutional structures serves to legitimate new issues in the public sphere and provides the impetus (and often the resources) for people to organize.

We also examine how particular factors - such as democracy or the influence of world society - affect some types of association more than others. Societal variables (education and wealth) largely explain variation in cultural and recreational groups. State and world society variables, however, substantially account for the expansion of social and political issue associations - the core infrastructure for modern politics and movements. Future research could explore this directly, tracing specific shifts in the agenda of the state (or international groups in world society), which may explain the rise of very specific types of associations. 


\section{Contributions}

Our contribution to the literature on voluntary associations (and "civil society," non-profits, etc.) is to pose this most fundamental question - the origins of association and to answer it with statistical analyses of a brand new cross-national, longitudinal dataset. To the individual-level literature on political participation and civic engagement, we bring much-needed attention to context - to the macro-level structures that support association, which are often overlooked. To the historical institutional literature in political sociology, focused mainly on case studies of affluent democracies, we bring efforts to distill and generalize. Drawing on that work, we articulate general features of the state - scope and openness- that are most salient to explain cross-national and temporal variation. Moreover, we highlight the importance of global forces, which are omitted from much case-based and Western-centric scholarship. Finally, we extend neoinstitutional research on world society by moving beyond the state to examine how global processes penetrate down into the domestic political sphere.

Turning beyond the scholarly literature, our findings challenge two ideas that dominate the public imagination. First is the notion, popular among American conservatives, that the state is somehow the enemy of voluntary association and civil society. Many believe the state "crowds out" association or that association thrives only when the state retreats or fails. We argue, and observe, the opposite: the state is very much an engine of association in modern societies. Rather than looking back to Toquevillian America to find the apex of associational life, one might instead look at the post-war era of rapidly expanding governments and large welfare states (e.g., Scandinavia). Second, much public discussion (and some scholarly work) imagines 
association to be a "grassroots" phenomenon, a spontaneous upwelling of individual voluntarism that manifests in the public sphere. Our study, consonant with much work by political sociologists and social movements researchers, points to the importance of institutional structures, opportunities, and legitimation. Associations do not just arise from society itself, they crystallize around the collective purposes, models, and resources provided by the state and other macro-social institutions.

\section{Global Institutionalization: Myths and Consequences?}

Central to our world society argument is the idea that "association" has become increasingly valued in modern world culture (also see Boli and Thomas 1999; Reimann 2006). This theme has emerged as part of a broader historical shift - often discussed under the rubric of "neo-liberalism" - that has rendered individuals, associations, and firms (as opposed to central governments) more central to visions of progress and development (Meyer, Drori, and Hwang 2006). It is no accident that fashionable buzzwords like 'social capital', 'civic engagement', and even references Putnam's work, appear on the web pages of the UN and the World Bank. The fact that the World Bank and other international organizations are providing funds for the expansion of domestic NGOs reflects the dominance and institutionalization of specific ideas about how to ameliorate social problems and generate societal development.

Ideas and discourses regarding association function as ideologies or 'myths' in world society, legitimating the use of funds for purposes that would have seemed ludicrous in prior decades - such as sponsoring community groups as opposed to, say, building roads or vaccinating children. The entire process can be viewed as a grand 
example of performativity (Mackenzie 2006), in which development experts and donors cultivate the civic association that is embedded in their (often neo-liberal) models of progress and development. The institutionalization of associations-as-myth in world society has profound implications for the international community and especially the developing world. International development organizations and financial institutions increasingly promote NGOs as "partners" in development planning (for an example, see Kagia 2005). Global environmental groups increasingly work to empower "local capacity" (Longhofer and Schofer 2010). And, domestic associations are incorporated into the international sphere itself. As putative representatives of local interests, associations are granted legitimate status within international organizations ("observers" or "consultative status") and are invited to function in various quasi-democratic and deliberative roles (e.g., representing local "stakeholders" who are consulted in the process of development planning).

In impoverished countries, these international forces overwhelmingly shape associational life. Observers are often struck by the degree to which associations may be externally oriented and exogenously funded (e.g., Dill 2009; Howell and Pearce 2001; Henderson 2002). The impact and efficacy of exogenously sponsored associations and "NGOs" is largely unknown, but there is tremendous faith that they represent a democratic and effective way to address a wide range of social ills. Scholars and development practitioners often vacillate between idealistic enthusiasm about the transformative possibilities of association and disillusionment with the "top-down" or "co-opted" (and sometimes obviously dysfunctional) character of many NGOs that result from donor aid or international policy initiatives. Yet, both optimists and cynics 
frequently share similar idealized models - a common myth of what associations ought to be able to accomplish. The neo-institutional lens seeks to expose the cultural myth, paving the way for a more straightforward empirical examination of their consequences (both intended and unintended), and the many possible forms of loose coupling that may occur when simplfied global models of association are implemented in complex and heterogeneous societies around the globe.

The actual consequences of voluntary associations (particularly those spawned by the international system) for key outcomes such as interest representation, social movement mobilization, policy reform, the provision of collective goods (e.g., successful development projects) represents a central direction for future research. The answers are not obvious. Exogenously supported associations may not represent "local" interests in the ways commonly imagined. The "boomerang effect," whereby local groups reach out to international allies, provides one imagery for understanding when local associations may generate effective social change (Keck and Sikkink 1998). Yet, our study and others may suggest "inverse boomerang" dynamics, as global movements and networks spawn domestic analogues - "squeezing" the state from above and below (Schofer and Hironaka 2006; Tsutsui and Shinn 2008; Longhofer and Schofer 2010). In other cases, domestic organizational spin-offs of international mobilization may prove epiphenomenal to larger global movements, with little independent impact of their own (Frank et al. 2007). Of course, global resources or links do not preclude the possibility that associations may be (or may eventually become) deeply embedded in national societies (Stark et al. 2006), altering their impact over time. And, the ascendance of associations-as-myth may increase their consequences, as associations are heaped with legitimacy and given greater 
accordance by formal structures of governance. Either way, our study hints at several important global-local dynamics that are not explored in the prior literature. 


\section{References}

Allison, Paul. 2009. Fixed Effects Regression Models. Los Angeles, CA: Sage.

Almond, Gabriel and Sidney Verba. 1963. The Civic Culture. Princeton, NJ: Princeton University Press.

Amenomori, Takayoshi. 1997. "Japan." Pp. 188-214 in Defining the Nonprofit Sector: A Cross-National Analysis, edited by L. M. Salamon and H. K. Anheier. Manchester [England]: Manchester University Press.

Andersen, Robert, James Curtis, and Edward Grabb. 2006. "Trends in Civic Association Activity in Four Democracies: The Special Case of Women in the United States." American Sociological Review 71(3): 376-400.

Andrews, Kenneth T. and Bob Edwards. 2004. "Advocacy Organizations in the U.S. Political Process.” Annual Review of Sociology 30: 479-506.

Andrews, Kenneth T., Marshall Ganz, Matthew Baggetta, Hahrie Han, and Chaeyoon Lim. 2010. "Leadership, Membership, and Voice: Civic Associations that Work." American Journal of Sociology 115(4): 1119-1242.

Angrist, Joshua and Jörn-Steffen Pischke. 2009. Mostly Harmless Econometrics: An Empiricist's Guide. Princeton, NJ: Princeton University Press.

Anheier, Helmut K., Mary H. Kaldor, and Marlies Glasius. 2004. Global Civil Society 2004/5. London: Sage.

Anheier, Helmut K. and Lester M. Salamon. 1998. The Nonprofit Sector in the Developing World: A Comparative Analysis. New York: Manchester University Press.

Arellano, Manuel and Olympia Bover. 1995. "Another Look at the Instrumental Variable Estimation of Error-components Models." Journal of Econometrics 68(1): 29-51.

Atingdui, Lawrence. 1997. "Ghana." Pp. 369-400 in Defining the Nonprofit Sector: A Cross-National Analysis, edited by L. M. Salamon and H. K. Anheier. Manchester [England]: Manchester University Press.

Baldassarri, Delia and Mario Diani. 2007. "The Integrative Power of Civic Networks." American Journal of Sociology 113(3): 735-780.

Banaszak, Lee Ann. 2010. The Women's Movement Inside and Outside of the State. Cambridge: Cambridge University Press.

Baltagi, Badi. 2008. Econometric Analysis of Panel Data, $4^{\text {th }}$ ed. Hoboken, NJ: Wiley. 
Banks, Arthur S. 2008. Cross-National Time-Series Data Archive [machine-readable data file]. Jerusalem, Israel: Databanks International.

Barr, Abigail, Marcel Fafchamps, and Trudy Owens. 2005. "The Governance of NonGovernmental Organizations in Uganda." World Development 33(4): 657-679.

Beck, Nathaniel and Jonathan N. Katz. 2009. "Modeling Dynamics in Time-SeriesCross-Section Political Economy Data." Working paper, New York University.

Benford, Robert D. and David A. Snow. 2000. "Framing Processes and Social Movements: An Overview and Assessment." Annual Review of Sociology 26:611-639.

Berman, Sheri. 1997. "Civil Society and the Collapse of the Weimar Republic." World Politics 49(3):401-429.

Blundell, R., and S. Bond. 1998. "Initial Conditions and Moment Restrictions in Dynamic Panel-Data Models.” Journal of Econometrics 87(1): 115-143.

Boli, John and George Thomas, eds. 1999. Constructing World Culture: International Non-Governmental Organizations since 1875. Stanford, CA: Stanford University Press.

Boli, John. 2005. "Contemporary Developments in World Culture.” International Journal of Comparative Sociology 46 (5/6): 383-404.

Brady, Henry E., Sidney Verba, and Kay Lehman Schlozman. 1995. "Beyond SES: A Resource Model of Political Participation." American Political Science Review 89(2): 271-294.

Brulle, Robert, Liesel Hall Turner, Jason Carmichael, and J. Craig Jenkins. 2007. "Measuring Social Movement Organization Populations: A Comprehensive Census of U.S. Environmental Organizations.” Mobilization 12(3): 195-211.

Caldwell, Lynton. 1990. Between Two Worlds: Science, the Environmental Movement, and Policy Choice. Cambridge: Cambridge University Press.

Campbell, Andrea Louise. 2002. "Self-Interest, Social Security, and the Distinctive Participation Patterns of Senior Citizens." American Political Science Review 96(3): 565574.

Chabbott, Colette. 1999. "Development INGOs." Pp. 222-248 in Constructing World Culture: International Non-Governmental Organizations since 1875, edited by J. Boli and G. Thomas. Stanford, CA: Stanford University Press

Chazan, Naomi. 1994. "Engaging the State: Associational Life in Sub-Saharan Africa." Pp. 255-289 in State Power and Social Forces, edited by J. Migdal, A. Kohli, and V. Shue. New York: Cambridge University Press. 
Clemens, Elisabeth. 1997. The People's Lobby: Organizational Innovation and the Rise of Interest Group Politics in the United States, 1890-1925. Chicago: University of Chicago Press.

Crowley, Jocelyn Elise and Theda Skocpol. 2001. "The Rush to Organize: Explaining Associational Formation in the United States, 1860s-1920s." American Journal of Political Science 45(4): 813-829.

Curtis, James E, Douglas E. Baer, and Edward G. Grabb. 2001. "Nations of Joiners: Explaining Voluntary Association Membership in Democratic Societies." American Sociological Review 66(6):783-805.

Das Gupta, Monica, Helene Grandvoinnet, and Mattia Romani. 2003. "Fostering Community-Driven Development: What Role for the State?" World Bank Policy Research Working Paper 2969. World Bank, Development Research Group, Washington, D. C.

Dill, Brian. 2009. "The Paradoxes of Community-Based Participation in Dar es Salaam, Tanzania." Development and Change 40(4): 717-743.

Driori, Gili, John W. Meyer, Francisco Ramirez, and Evan Schofer. 2003. Science in the Modern World Polity: Institutionalization and Globalization. Stanford, CA: Stanford University Press.

Edwards, Bob, and Kenneth T. Andrews. 2002. "Methodological Strategies for Examining Populations of Social Movement Organizations." Paper presented at the annual meeting of the American Sociological Association, Chicago, Illinois, August 2002.

Evans, Peter. 1995. Embedded Autonomy: States and Industrial Transformation. Princeton, NJ: Princeton University Press.

Fourcade, Marion. 2006. "The Construction of a Global Profession: The Transnationalization of Economics." American Journal of Sociology 112(1): 145-94.

Frank, David John, Ann Hironaka, and Evan Schofer. 2000. "The Nation-State and the Natural Environment Over the Twentieth Century." American Sociological Review 65(1): 96-116.

Frank, David John, Wesley Longhofer, and Evan Schofer. 2007. "World Society, NGOs, and Environmental Policy Reform in Asia." International Journal of Comparative of Sociology 48(4): 275-295.

Freedom House. 2009. Freedom in the World 2009: The Annual Survey of Political Rights and Civil Liberties. Lanham, MD: Rowman \& Littlefield. 
Gale. 2010. Encyclopedia of Associations: International Organizations, $49^{\mathrm{h}} \mathrm{ed}$.

Florence, KY: Gale Cengage Learning.

Gerring, John and Strom C. Thacker. 2004. "Political Institutions and Corruption: The Role of Unitarism and Parlimentarism." British Journal of Political Science 34(2): 295330 .

Gourinchas, Marion F. and Evan Schofer. 2004. "The Multifaceted Nature of Civic Engagement: Forms of Political Activity in Comparative Perspective." Presented at the annual conference of the Social Science and History Association, Chicago, November 18, 2004.

Greene, William H. 2008. Econometric Analysis, $6^{\text {th }}$ ed. Upper Saddle River, NJ: Prentice Hall.

Gurr, Ted R. 1989. POLITY II: POLITICAL STRUCTURES AND REGIME CHANGE, 1800-1986 [Computer file]. Boulder, CO: Center for Comparative Politics.

Haas, Peter. 1992. "Introduction: Epistemic Communities and International Policy Coordination." International Organization 46(1): 1-35.

Halaby, Charles N. 2004. "Panel Models in Sociological Research: Theory into Practice." Annual Review of Sociology 30: 507-544.

Hansen, Lars Peter. 1982. "Large sample properties of generalized method of moments estimators." Econometrica 50(3): 1029-1054.

Henderson, Sarah L. "Selling Civil Society: Western Aid and the Nongovernmental Sector in Russia." Comparative Political Studies 35(2): 139-167.

Hironaka, Ann. 2002. "The Globalization of Environmental Protection: The Case of Environmental Impact Assessment." International Journal of Comparative Sociology 43(1): 65-78.

Hironaka, Ann. 2005. Neverending Wars: Weak States, the International Community, and the Perpetuation of Civil War. Cambridge, MA: Harvard University Press.

Howell, Jude and Jenny Pearce. 2001. Civil Society and Development: A Critical Exploration. Boulder, CO: Lynne Rienner.

Huber, Peter J. 1967. "The Behavior of Maximum Likelihood Estimates under Nonstandard Conditions," Proceedings of the Fifth Berkeley Symposium on Mathematical Statistics and Probability vol. I: 221-233.

Inglehart, Ronald. 1997. Modernization and Postmodernization: Cultural, Economic and Political Change in 43 Societies. Princeton, NJ: Princeton University Press. 
Inkeles, Alex D. and David H. Smith. 1976. Becoming Modern: Individual Change in Six Developing Countries. Cambridge, MA: Harvard University Press.

Jaggers, Keith, and Ted Robert Gurr. 1995. Polity III: Regime Change and Political Authority, 1800-1994. Ann Arbor, MI: ICPSR.

Jepperson, Ronald. 1992. "National Scripts: The Varying Construction of Individualism and Opinion across the Modern Nation-States." Unpublished PhD Dissertation, Yale University.

Jepperson, Ronald. 2002. "Political Modernities: Disentangling Two Underlying Dimensions of Institutional Differentiation." Sociological Theory 20(1):61-85.

Joyce, Michael S. and William A. Schambra. 1996. "A New Civic Life.” Pp. 15-25 in To Empower People: From State to Civil Society, $2^{\text {nd }}$ ed., edited by M. Novak. Washington, DC: AEI Press.

Kagia, Ruth. 2005. A New Development Agenda: The Transformation of the World Bank Under James D. Wolfensohn, 1995-2005. Washington, DC: World Bank Publications.

Kaldor, Mary H., Helmut K. Anheier, and Marlies Glasius. 2003. Global Civil Society Yearbook 2003. Oxford: Oxford University Press.

Longhofer, Wesley and Evan Schofer. 2010. "National and Global Origins of Environmental Association.” American Sociological Review 71(4): 505-533.

Lundström, Tommy and Filip Wijkström. 1997. "Sweden.” Pp. 215-248 in Defining the Nonprofit Sector: A Cross-National Analysis, edited by L. M. Salamon and H. K. Anheier. Manchester [England]: Manchester University Press.

McAdam, Douglas, John McCarthy and Mayer Zald (eds.) 1996. Comparative Perspectives on Social Movements. Political Opportunities, Mobilizing Structures and Cultural Framings. Cambridge [England]: Cambridge University Press.

Mettler, Suzanne. 2002. "Bringing the State Back In to Civic Engagement: Policy Feedback Effects of the G.I. Bill for World War II Veterans." American Political Science Review 96(2): 351-365.

Meyer, David S. 2004. "Protest and Political Opportunities." Annual Review of Sociology 30:125-198.

Meyer, John W. 1987. "The World Polity and the Authority of the Nation-State." Pp. 41 70 in Institutional Structure: Constituting State, Society and the Individual, edited by G.M. Thomas, J.W. Meyer, F.O. Ramirez, and J. Boli. Newbury Park, CA: Sage. 
Meyer, John W., John Boli, George Thomas, and Francisco O. Ramirez. 1997. "World Society and the Nation-State." American Journal of Sociology 103(1):144-181.

Meyer, John W., David John Frank, Ann Hironaka, Evan Schofer, and Nancy Brandon Tuma. 1997. "The Structuring of a World Environmental Regime, 1870-1990." International Organization 51(4):623-651.

Minkoff, Debra. 2002. "Macro-Organizational Analysis.” Pp. 260-285 in Methods of Social Movement Research, edited by B. Klandermans and S. Staggenborg. Minneapolis: University of Minnesota Press.

Minkoff, Debra, Silke Aisenbery, and Jon Agnone. 2008. "Organizational Diversity in the U.S. Advocacy Sector." Social Problems 55(4): 525-548.

Minkoff, Debra and John D. McCarthy. 2005. "Reinvigorating the Organizational Processes of Social Movements." Mobilization 10(2): 401-21.

Nelson, Paul J. 1995. The World Bank and Non-Governmental Organizations: The Limits of Apolitical Development. New York: St. Martin's Press.

Nickell, Stephen J. 1981. "Biases in Dynamic Models with Fixed Effects." Econometrica 49(6):1417-1426.

Orum, Anthony M. 1989. Introduction to Political Sociology. Upper Saddle River, NJ: Prentice Hall.

Opitz, Helmut (ed.). 2002. World Guide to Scientific Associations and Learned Societies, $8^{\text {th }}$ ed. München [Germany]: K.G. Saur.

Paxton, Pamela. 2007. "Association Memberships and Generalized Trust: A multilevel Model Across 31 Countries." Social Forces 86(1): 47-76.

Paxton, Pamela. 2002. "Social Capital and Democracy: An Interdependent Relationship." American Sociological Review 67(2): 254-277.

Pierson, Paul. 1993. "When Effect Becomes Cause: Policy Feedback and Political Change." World Politics 45(4): 595-628.

Plumper, Thomas, Vera E. Troeger, and Manow. 2005. "Panel Data in Comprative Politics: Linking Method to Theory." European Journal of Political Research 44(2): 327354.

Pongsapich, Amara. 1997. "Thailand.” Pp. 446-468 in Defining the Nonprofit Sector: A Cross-National Analysis, edited by L. M. Salamon and H. K. Anheier. Manchester [England]: Manchester University Press. 
Putnam, Robert. 2000. Bowling Alone: The Collapse and Revival of American Community. New York: Simon and Schuster.

Putnam, Robert, et al. 1993. Making Democracy Work. Princeton, N.J.: Princeton University Press.

Ramirez, Francisco, Yasemin Soysal, and Suzanne Shanahan. 1997. "The Changing Logic of Political Citizenship: Cross-National Acquisition of Women's Suffrage Rights, 1890-1990." American Sociological Review 62(5): 735-745.

Reger, Jo and Suzanne Staggenborg. 2006. "Patterns of Mobilization in Local Movement Organizations: Leadership and Strategy in Four National Organization for Women Chapters." Sociological Perspectives 49(3): 297-323.

Reimann, Kim D. 2006. "A View From the Top: International Politics, Norms, and the Worldwide Growth of NGOs." International Studies Quarterly 50(1):45-67.

Roßteutscher, Sigrid. 2010. "Social Capital Worldwide: Potential for Democratization or Stabilizer of Authoritarian Rule?" American Behavioral Scientist 53(5): 737-757.

Rothstein, Bo. 2002. "Social Capital in the Social Democratic Welfare State." Politics \& Society 29(2): 207-241.

Ruiter, Stijn and Nan Dirk De Graaf. 2006. "National Context, Religiosity, and Volunteering: Results from 53 Countries." American Sociological Review 71(2): 191210.

Salamon, Lester and Helmut Anheier, eds. 1996. Defining the Nonprofit Sector: A Crossnational Analysis. Manchester [England]: Manchester University Press.

Salamon, Lester and Helmut Anheier. 1998. "Social Origins of Civil Society: Explaining the Non-Profit Sector Cross-Nationally." Voluntas 9(3): 213-248.

Salamon, Lester, S. Wojciech Sokolowski, and Associates. 2004. Global Civil Society: Dimensions of the Non-Profit Sector, Volume II. Bloomfield, CT: Kumarian Press.

Sampson, Robert J., Doug McAdam, Heather MacIndoe, and Simon Weffer-Elizondo. 2005. "Civil Society Reconsidered: The Durable Nature and Community Structure of Collective Civic Action." American Journal of Sociology 111(3): 673-714.

Sarkees, Meredith Reid. 2000. "The Correlates of War Data on War: An Update to 1997." Conflict Management and Peace Science 18(1): 123-144.

Schneider, Aaron. 2003. "Decentralization: Conceptualization and Measurement." Studies in Comparative International Development 38(3): 32-56. 
Schofer, Evan. 1999. "Science Associations in the International Sphere, 1875-1990: The Rationalization of Science and the Scientization of Society." Pp. 249-266 in Constructing World Culture: International Non-Governmental Organizations since 1875, edited by J. Boli and G. Thomas. Stanford: Stanford University Press

Schofer, Evan. 2003. "The Global Institutionalization of Geological Science, 18001990." American Sociological Review 68 (5): 730-759.

Schofer, Evan. 2004. "Cross-national Variation in the Expansion of Western Science." Social Forces 83(1): 215-247.

Schofer, Evan and Marion Fourcade-Gourinchas. 2001. "The Structural Contexts of Civic Engagement. Voluntary Associations Membership in Comparative Perspective." American Sociological Review 66(6): 806-828.

Simmons, Beth A. 2009. Mobilizing for Human Rights: International Law in Domestic Politics. Cambridge [UK]: Cambridge University Press.

Siri, Gabriel. 2002. "The World Bank and Civil Society Development: Exploring Two Courses of Action for Capacity Building.” Washington, DC: World Bank Institute Working Papers.

Skocpol, Theda and Morris P. Fiorina, eds. 1999. Civic Engagement in American Democracy. Washington, DC: Brookings Institute Press.

Skocpol, Theda, Marshall Ganz, and Ziad Munson. 2000. "A Nation of Organizers: The Institutional Origins of Civic Voluntarism in the United States." American Political Science Review 94(3): 527-546.

Skocpol, Theda. 2003. Diminished Democracy: From Membership to Management in American Civic Life. Norman, OK: University of Oklahoma Press.

Soss, Joe and Sanford F. Schram. 2007. "A Public Transformed? Welfare Reform as Policy Feedback.” American Political Science Review 101(1): 111-127.

Stark, David, Balaza Vedres, and Laszlo Bruszt. 2006. "Rooted Transnational Publics: Integrating Foreign Ties and Civic Activism. Theory and Society 35(3): 323-349.

Tarrow, Sidney. 1998. Power in Movement: Social Movements and Contentious Politics, $2^{\text {nd }}$ ed. Cambridge [England]: Cambridge University Press.

Thomas, George, John Meyer, Francisco Ramirez, and John Boli, eds. 1987. Institutional Structure: Constituting State, Society, and the Individual. Newbury Park: Sage Publications. 
Tilly, Charles. 1985. "War Making and State Making as Organized Crime.” Pp. 169-191 in Bringing the State Back In, edited by P. Evans, D. Rueschemeyer, and T. Skocpol. New York: Cambridge University Press.

Tilly, Charles. 1992. Coercion, Capital, and European States, AD 990-1992 (Studies in Social Discontinuity). Malden, MA: Blackwell Publishers.

Tocqueville, Alexis de. 2000 (1835 and 1840). Democracy in America. Chicago: University of Chicago Press.

Tripp, Aili Mari. 1997. Changing the Rules: The Politics of Liberalization and the Urban Informal Economy in Tanzania. Berkeley, CA: University of California Press.

Tryzna, Ted and Elizabeth Davidson. 2001. World Directory of Environmental Organizations, $6^{\text {th }}$ ed. Claremont, CA: California Institute of Public Affairs.

Tsutsui, Kiyoteru. 2008. “"Redressing Past Human Rights Violations: Global Dimensions of Contemporary Social Movements.” Social Forces 85(1): 331-354.

Uhlin, Anders. 2002. "Globalization, democratization and civil society in Southeast Asia: observations from Malaysia and Thailand.” Pp. 149-166 in Globalization and Democratization in Asia: The Construction of Identity, edited by $\mathrm{C}$. Kinnvall and $\mathrm{K}$. Jönsson. New York: Routledge.

Union of International Associations, various years. Yearbook of International Organizations. Brussels [Belgium]: Union of International Associations.

Walker, Edward, John D. McCarthy, and Frank Baumgartner. 2011. "Replacing Members with Managers? Mutualism among Membership and Non-membership Advocacy Organizations in the U.S." American Journal of Sociology 116(4): 1281-1337.

Wapner, Paul. 1996. Environmental Activism and World Civic Politics. Albany, NY: State University of New York Press.

Weir, Margaret and Marshall Ganz. 1995. "Reconnecting People and Politics." Pp. 149171 in The New Majority: Toward a Popular Progressive Politics, edited by S.B. Greenberg and T. Skocpol. New Haven, CT: Yale University Press.

Williams, R.L. 2000. "A Note on Robust Variance Estimate for Cluster-Correlated Data." Biometrics 56(2): 645-646.

Wollebæk, Dag and Kristin Strømsnes. 2008. "Voluntary Associations, Trust, and Civic Engagement: A Multilevel Approach.” Nonprofit and Voluntary Sector Quarterly 37(2): 249-263. 
Wooldridge, Jeffrey. 2002. Econometric Analysis of Cross Section and Panel Data.

Cambridge, MA: MIT Press.

World Bank. 2010. World Development Indicators 2010. Washington, D.C.: World Bank. 
Table 1. Fixed Effects Panel Regression Models Predicting the Overall Level of Association in Society, 1970-2006

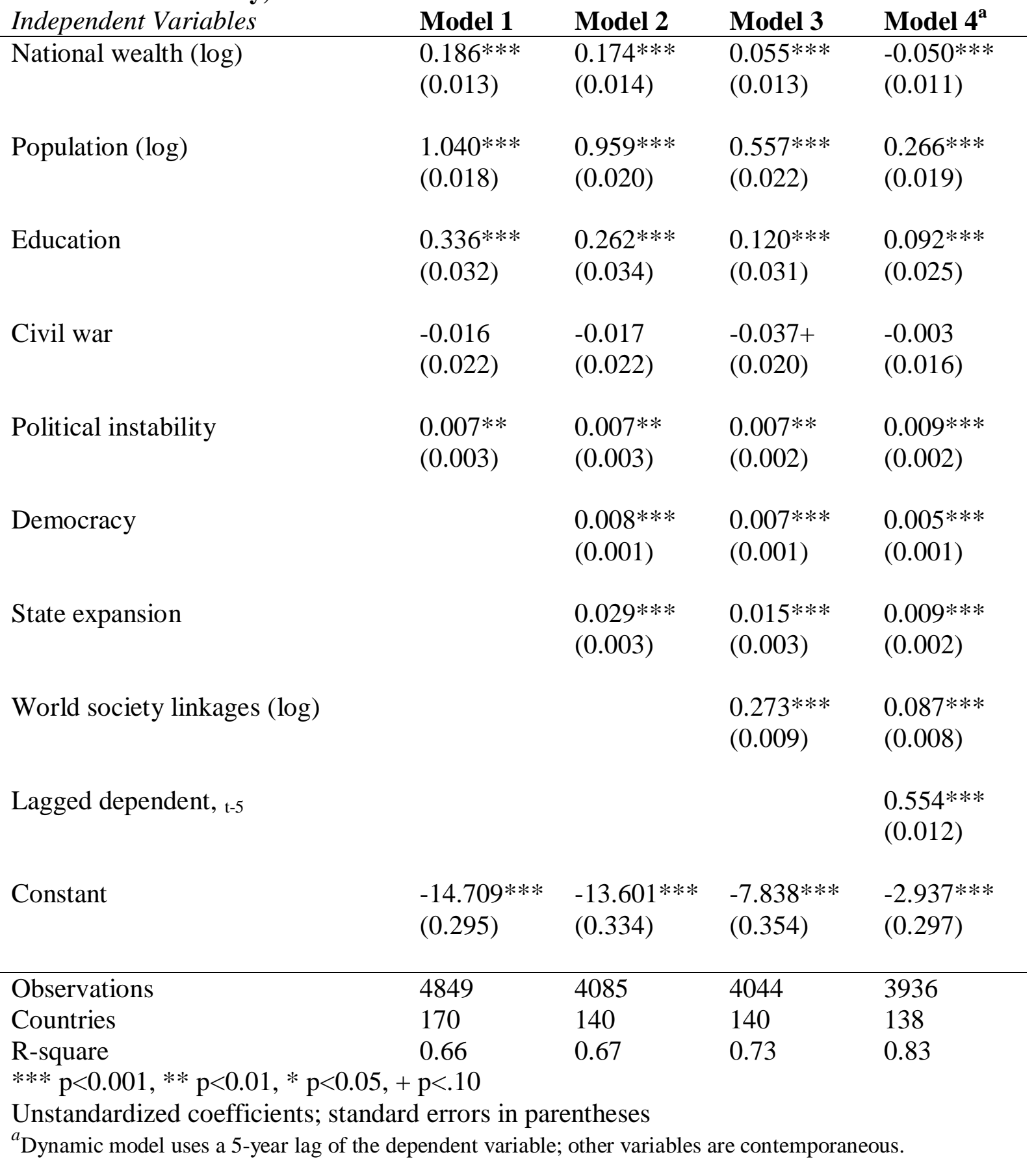


Table 2. Sensitivity Analyses Replicating Key Findings: GMM Panel Regression Models Predicting the Overall Level of Association in Society, 1970-2006

\begin{tabular}{|c|c|c|}
\hline Independent Variables & $\begin{array}{l}\text { Model } 5 \\
I V G M M^{a}\end{array}$ & $\begin{array}{l}\text { Model } 6 \\
\text { IV GMM 5-yr }\end{array}$ \\
\hline National wealth (log) & $\begin{array}{l}0.463 * * * \\
(0.002)\end{array}$ & $\begin{array}{l}0.398^{* * * *} \\
(0.005)\end{array}$ \\
\hline Population (log) & $\begin{array}{l}0.509 * * * \\
(0.001)\end{array}$ & $\begin{array}{l}0.491 * * * \\
(0.004)\end{array}$ \\
\hline Education & $\begin{array}{l}1.112 * * * \\
(0.007)\end{array}$ & $\begin{array}{l}0.994 * * * \\
(0.021)\end{array}$ \\
\hline Civil war & $\begin{array}{l}-0.060 * * * \\
(0.006)\end{array}$ & $\begin{array}{l}-0.107 * * * \\
(0.008)\end{array}$ \\
\hline Political instability & $\begin{array}{l}0.008 * * * \\
(0.001)\end{array}$ & $\begin{array}{l}0.013 * * * \\
(0.002)\end{array}$ \\
\hline Democracy & $\begin{array}{l}0.023 * * * \\
(0.000)\end{array}$ & $\begin{array}{l}0.013 * * * \\
(0.002)\end{array}$ \\
\hline State expansion & $\begin{array}{l}0.014 * * * \\
(0.002)\end{array}$ & $\begin{array}{l}0.075 * * * \\
(0.005)\end{array}$ \\
\hline World society linkages (log) & $\begin{array}{l}0.007^{*} \\
(0.003)\end{array}$ & $\begin{array}{l}0.088 * * * \\
(0.011)\end{array}$ \\
\hline Constant & $\begin{array}{l}-9.023 * * * \\
(0.014)\end{array}$ & $\begin{array}{l}-8.718^{* * * *} \\
(0.039)\end{array}$ \\
\hline $\begin{array}{l}\text { Observations } \\
\text { Countries } \\
* * * \mathrm{p}<0.001, * * \mathrm{p}<0.01, * \mathrm{p}< \\
\text { Unstandardized }\end{array}$ & $\begin{array}{l}4071 \\
140 \\
0.05,+\mathrm{p}<.1\end{array}$ & arentheces \\
\hline \multicolumn{3}{|c|}{$\begin{array}{l}\text { Unstandardized coefficients; standard errors in parentheses } \\
{ }^{a} \text { Democracy, state expansion, and world polity linkages are treated as potentially endogenous. Two to five } \\
\text { year lags of differences, inclusive, and all available lags of levels are used as instruments. }\end{array}$} \\
\hline
\end{tabular}


Table 3. Fixed Effects Panel Regression Models Predicting the Overall Level of Association in Society, With Additional State Measures, 1970-2006

\begin{tabular}{|c|c|c|}
\hline Independent Variables & Model 7 & Model 8 \\
\hline \multirow[t]{2}{*}{ National wealth (log) } & $0.170 * * *$ & $0.389 * * *$ \\
\hline & $(0.014)$ & $(0.021)$ \\
\hline \multirow[t]{2}{*}{ Population (log) } & $0.983 * * *$ & $0.611 * * *$ \\
\hline & $(0.020)$ & $(0.037)$ \\
\hline \multirow[t]{2}{*}{ Education } & $0.232 * * *$ & $0.001 *$ \\
\hline & $(0.034)$ & $(0.000)$ \\
\hline \multirow[t]{2}{*}{ Civil war } & -0.017 & -0.032 \\
\hline & $(0.022)$ & $(0.038)$ \\
\hline \multirow[t]{2}{*}{ Political instability } & $0.008 * *$ & 0.003 \\
\hline & $(0.003)$ & $(0.004)$ \\
\hline \multirow[t]{2}{*}{ Democracy } & $0.008 * * *$ & $0.014 * * *$ \\
\hline & $(0.001)$ & $(0.001)$ \\
\hline \multirow[t]{2}{*}{ State expansion } & $0.028 * * *$ & $0.046 * * *$ \\
\hline & $(0.003)$ & $(0.004)$ \\
\hline \multirow[t]{2}{*}{ State expansion X democracy } & $0.002 * * *$ & \\
\hline & $(0.000)$ & \\
\hline \multirow[t]{2}{*}{ Decentralization } & & $0.145^{* *}$ \\
\hline & & $(0.046)$ \\
\hline \multirow[t]{2}{*}{ Constant } & $-13.955 * * *$ & $-8.477 * * *$ \\
\hline & $(0.337)$ & $(1.564)$ \\
\hline Observations & 4085 & 1772 \\
\hline Countries & 140 & 60 \\
\hline R-square & 0.67 & --- \\
\hline \multicolumn{3}{|c|}{$* * * \mathrm{p}<0.001, * * \mathrm{p}<0.01, * \mathrm{p}<0.05,+\mathrm{p}<.10$} \\
\hline
\end{tabular}


Table 4. Fixed Effects Panel Regression Models Predicting the Overall Level of Association in Society, With Additional World Society Measures, 1970-2006

\begin{tabular}{|c|c|c|c|}
\hline Independent Variables & $\begin{array}{l}\text { Model } 9 \\
\text { All Countries }\end{array}$ & $\begin{array}{l}\text { Model 10 } \\
\text { Low GDP }\end{array}$ & $\begin{array}{l}\text { Model 11 } \\
\text { Low GDP }\end{array}$ \\
\hline National wealth (log) & $\begin{array}{l}0.026+ \\
(0.014)\end{array}$ & $\begin{array}{l}0.076 * * * \\
(0.017)\end{array}$ & $\begin{array}{l}0.071 * * * \\
(0.015)\end{array}$ \\
\hline Population (log) & $\begin{array}{l}0.423 * * * \\
(0.027)\end{array}$ & $\begin{array}{l}0.569 * * * \\
(0.030)\end{array}$ & $\begin{array}{l}0.518 * * * \\
(0.027)\end{array}$ \\
\hline Education & $\begin{array}{l}-0.003 \\
(0.034)\end{array}$ & $\begin{array}{l}0.082+ \\
(0.046)\end{array}$ & $\begin{array}{l}-0.033 \\
(0.044)\end{array}$ \\
\hline Civil war & $\begin{array}{l}-0.033+ \\
(0.020)\end{array}$ & $\begin{array}{l}-0.029 \\
(0.021)\end{array}$ & $\begin{array}{l}-0.035+ \\
(0.021)\end{array}$ \\
\hline Political instability & $\begin{array}{l}0.007 * * \\
(0.002)\end{array}$ & $\begin{array}{l}0.008 * * \\
(0.003)\end{array}$ & $\begin{array}{l}0.011 * * * \\
(0.003)\end{array}$ \\
\hline Democracy & $\begin{array}{l}0.005 * * * \\
(0.001)\end{array}$ & $\begin{array}{l}0.005^{* * * *} \\
(0.001)\end{array}$ & $\begin{array}{l}0.007 * * * \\
(0.001)\end{array}$ \\
\hline State expansion & $\begin{array}{l}0.017 * * * \\
(0.003)\end{array}$ & $\begin{array}{l}0.014 * * * \\
(0.003)\end{array}$ & $\begin{array}{l}0.020 * * * \\
(0.003)\end{array}$ \\
\hline World society linkages (log) & $\begin{array}{l}0.228 * * * \\
(0.010)\end{array}$ & $\begin{array}{l}0.259 * * * \\
(0.013)\end{array}$ & $\begin{array}{l}0.261 * * * \\
(0.010)\end{array}$ \\
\hline
\end{tabular}

World society structuration $(\log ) \quad 0.220 * * *$

$(0.025)$

Aid

$0.001 *$

(0.001)

World Bank projects

$0.058 * * *$

(0.010)

Constant

$-6.976 * * *$

$-8.545^{* * *}$

$-7.606 * * *$

$(0.365)$

$(0.455)$

(0.433)

$\begin{array}{llll}\text { Observations } & 4044 & 2842 & 3107 \\ \text { Countries } & 140 & 104 & 114 \\ \text { R-square } & 0.73 & 0.71 & 0.71\end{array}$

$* * * \mathrm{p}<0.001, * * \mathrm{p}<0.01, * \mathrm{p}<0.05,+\mathrm{p}<.10$

Unstandardized coefficients; standard errors in parentheses 
Table 5. Fixed Effects Panel Regression Models Predicting the Level of Association, Disaggregated by Type, 1970-2006

\begin{tabular}{|c|c|c|c|c|}
\hline Independent Variables & $\begin{array}{l}\text { Model } 12 \\
\text { Social/Political }\end{array}$ & $\begin{array}{l}\text { Model 13 } \\
\text { Trade }\end{array}$ & $\begin{array}{l}\text { Model } 14 \\
\text { Professional }\end{array}$ & $\begin{array}{l}\text { Model } 15 \\
\text { Cultural }\end{array}$ \\
\hline National wealth (log) & $\begin{array}{l}0.037 * \\
(0.016)\end{array}$ & $\begin{array}{l}0.154 * * * \\
(0.014)\end{array}$ & $\begin{array}{l}0.204 * * * \\
(0.018)\end{array}$ & $\begin{array}{l}0.080 * * * \\
(0.014)\end{array}$ \\
\hline Population (log) & $\begin{array}{l}0.433 * * * \\
(0.027)\end{array}$ & $\begin{array}{l}0.023 \\
(0.023)\end{array}$ & $\begin{array}{l}0.530 * * * \\
(0.030)\end{array}$ & $\begin{array}{l}0.284 * * * \\
(0.024)\end{array}$ \\
\hline Education & $\begin{array}{l}0.108 * * \\
(0.038)\end{array}$ & $\begin{array}{l}0.182 * * * \\
(0.033)\end{array}$ & $\begin{array}{l}0.300 * * * \\
(0.042)\end{array}$ & $\begin{array}{l}0.349 * * * \\
(0.034)\end{array}$ \\
\hline Civil war & $\begin{array}{l}-0.062 * \\
(0.025)\end{array}$ & $\begin{array}{l}-0.021 \\
(0.021)\end{array}$ & $\begin{array}{l}-0.050+ \\
(0.028)\end{array}$ & $\begin{array}{l}-0.014 \\
(0.022)\end{array}$ \\
\hline Political instability & $\begin{array}{l}0.008 * * \\
(0.003)\end{array}$ & $\begin{array}{l}-0.001 \\
(0.003)\end{array}$ & $\begin{array}{l}-0.004 \\
(0.003)\end{array}$ & $\begin{array}{l}-0.001 \\
(0.003)\end{array}$ \\
\hline Democracy & $\begin{array}{l}0.014 * * * \\
(0.001)\end{array}$ & $\begin{array}{l}0.005 * * * \\
(0.001)\end{array}$ & $\begin{array}{l}0.004 * * * \\
(0.001)\end{array}$ & $\begin{array}{l}0.001 \\
(0.001)\end{array}$ \\
\hline State expansion & $\begin{array}{l}0.033 * * * \\
(0.003)\end{array}$ & $\begin{array}{l}0.016^{* * * *} \\
(0.003)\end{array}$ & $\begin{array}{l}0.011 * * \\
(0.004)\end{array}$ & $\begin{array}{l}0.001 \\
(0.003)\end{array}$ \\
\hline $\begin{array}{l}\text { World society linkages } \\
(\log )\end{array}$ & $\begin{array}{l}0.298 * * * \\
(0.011)\end{array}$ & $\begin{array}{l}0.202^{* * * *} \\
(0.009)\end{array}$ & $\begin{array}{l}0.139 * * * \\
(0.012)\end{array}$ & $\begin{array}{l}0.112 * * * \\
(0.010)\end{array}$ \\
\hline Constant & $\begin{array}{l}-6.928 * * * \\
(0.426)\end{array}$ & $\begin{array}{l}-0.830 * \\
(0.369)\end{array}$ & $\begin{array}{l}-9.136 * * * \\
(0.481)\end{array}$ & $\begin{array}{l}-4.440 * * * \\
(0.380)\end{array}$ \\
\hline $\begin{array}{l}\text { Observations } \\
\text { Countries } \\
\mathrm{R} \text {-square } \\
* * * \mathrm{p}<0.001, * * \mathrm{p}<0.01\end{array}$ & $\begin{array}{l}4044 \\
140 \\
0.66 \\
0.05,+p<.10\end{array}$ & $\begin{array}{l}4044 \\
140 \\
0.45\end{array}$ & $\begin{array}{l}4044 \\
140 \\
0.51\end{array}$ & $\begin{array}{l}4044 \\
140 \\
0.42\end{array}$ \\
\hline
\end{tabular}


Appendix A. Descriptive Statistics

\begin{tabular}{llll}
\hline Variable & Observations & Mean & S.D. \\
\hline Total associations & 4044 & 154.86 & 527.84 \\
Total associations (logged) & 4044 & 3.307 & 1.698 \\
Trade associations & 4044 & 38.35 & 124.08 \\
Trade associations (logged) & 4044 & 2.05 & 1.65 \\
Social/political associations & 4044 & 35.90 & 120.74 \\
Social/political associations (logged) & 4044 & 2.26 & 1.41 \\
Professional associations & 4044 & 43.03 & 135.69 \\
Professional associations (logged) & 4044 & 1.94 & 1.79 \\
Cultural associations & 4044 & 26.43 & 107.49 \\
Cultural associations (logged) & 4044 & 1.60 & 1.46 \\
GDP per capita & 4044 & 5351.55 & 8107.45 \\
GDP per capita (logged) & 4044 & 7.440 & 1.589 \\
Population & 4044 & 38000000 & 130000000 \\
Population (logged) & 4044 & 16.079 & 1.484 \\
Civil war year & 4044 & 0.019 & 0.138 \\
Political instability & 4044 & 1.203 & 1.451 \\
Secondary education & 4044 & 55.027 & 33.481 \\
Democracy & 4044 & 1.165 & 7.455 \\
State expansion index & 4044 & 0.911 & 2.410 \\
Decentralization & 1772 & 0.411 & 2.670 \\
INGO memberships & 4044 & 76.51 & 779.37 \\
INGO memberships (logged) & 4044 & 6.153 & 1.046 \\
Total INGOs, world-level (logged) & 4044 & 8.403 & 0.340 \\
World Bank civil society projects & 4044 & 0.238 & 0.426 \\
Aid as percent of GDP & 3001 & 6.830 & 8.866
\end{tabular}




\begin{tabular}{|c|c|c|c|c|}
\hline Variable & Description & Transformation & Years & Source \\
\hline \multicolumn{5}{|l|}{ Dependent } \\
\hline EA Associations & $\begin{array}{l}\text { Cumulative sum based on } \\
\text { founding dates }\end{array}$ & Logged & $1970-2006$ & Gale 2010 \\
\hline \multicolumn{5}{|l|}{ Independent } \\
\hline National wealth & $\begin{array}{l}\text { GDP per capita, constant } \\
\text { US\$ }\end{array}$ & Logged & $1970-2006$ & $\begin{array}{l}\text { World Bank } \\
2010\end{array}$ \\
\hline Population & Total population & Logged & $1970-2006$ & $\begin{array}{l}\text { World Bank } \\
2010\end{array}$ \\
\hline Civil war & Dummy, $1=$ civil war & & $1970-2006$ & Sarkees 2000 \\
\hline Political instability & $\begin{array}{l}\text { Index of political } \\
\text { instability and violence }\end{array}$ & $\begin{array}{l}\text { Divided by } 100, \\
\text { logged }\end{array}$ & $1970-2006$ & Banks 2008 \\
\hline Education & $\begin{array}{l}\text { Secondary enrollment } \\
\text { ratios (percent gross) }\end{array}$ & Divided by 100 & $1970-2006$ & $\begin{array}{l}\text { World Bank } \\
2010\end{array}$ \\
\hline Democracy & $\begin{array}{l}\text { Index of civil liberties and } \\
\text { political freedoms } \\
\text { 1=low, 14=high }\end{array}$ & & $1970-2006$ & $\begin{array}{l}\text { Freedom } \\
\text { House } 2009\end{array}$ \\
\hline State expansion index & $\begin{array}{l}\text { Index of government } \\
\text { expenditures as percent of } \\
\text { GDP, social transfers as } \\
\text { percent of GDP, and } \\
\text { legislative effectiveness }\end{array}$ & $\begin{array}{l}\text { Sum of z-scores; } \\
\text { Expenditures and } \\
\text { social transfers } \\
\text { logged }\end{array}$ & $1970-2006$ & $\begin{array}{l}\text { World Bank } \\
\text { 2010; Banks } \\
2008\end{array}$ \\
\hline World society linkages & $\begin{array}{l}\text { International non- } \\
\text { governmental organization } \\
\text { memberships }\end{array}$ & Logged & $1970-2006$ & $\begin{array}{l}\text { UIA, various } \\
\text { years }\end{array}$ \\
\hline $\begin{array}{l}\text { World society } \\
\text { structuration }\end{array}$ & $\begin{array}{l}\text { Total international non- } \\
\text { governmental } \\
\text { organizations, world-level }\end{array}$ & Logged & $1970-2006$ & $\begin{array}{l}\text { UIA, various } \\
\text { years }\end{array}$ \\
\hline World Bank projects & $\begin{array}{l}\text { Cumulative projects with a } \\
\text { civic engagement theme }\end{array}$ & Logged & $1970-2006$ & $\begin{array}{l}\text { World Bank } \\
\text { projects } \\
\text { database } \\
\text { (online) }\end{array}$ \\
\hline Aid & $\begin{array}{l}\text { Official development } \\
\text { assistance as percent of } \\
\text { GDP }\end{array}$ & & $1970-2006$ & $\begin{array}{l}\text { World Bank } \\
2010\end{array}$ \\
\hline $\begin{array}{l}\text { State expansion * } \\
\text { democracy }\end{array}$ & $\begin{array}{l}\text { Interaction term of mean- } \\
\text { centered state expansion } \\
\text { and democracy }\end{array}$ & & & \\
\hline Decentralization & $\begin{array}{l}\text { Index of fiscal } \\
\text { decentralization, } \\
\text { federalism, and non- } \\
\text { statism }\end{array}$ & Sum of z-scores & $\begin{array}{l}\text { Non-time } \\
\text { varying }\end{array}$ & $\begin{array}{l}\text { Schenider } \\
\text { 2003; Gerring } \\
\text { and Thacker } \\
\text { 2004; } \\
\text { Jepperson } \\
\text { 1992, 2002 }\end{array}$ \\
\hline
\end{tabular}




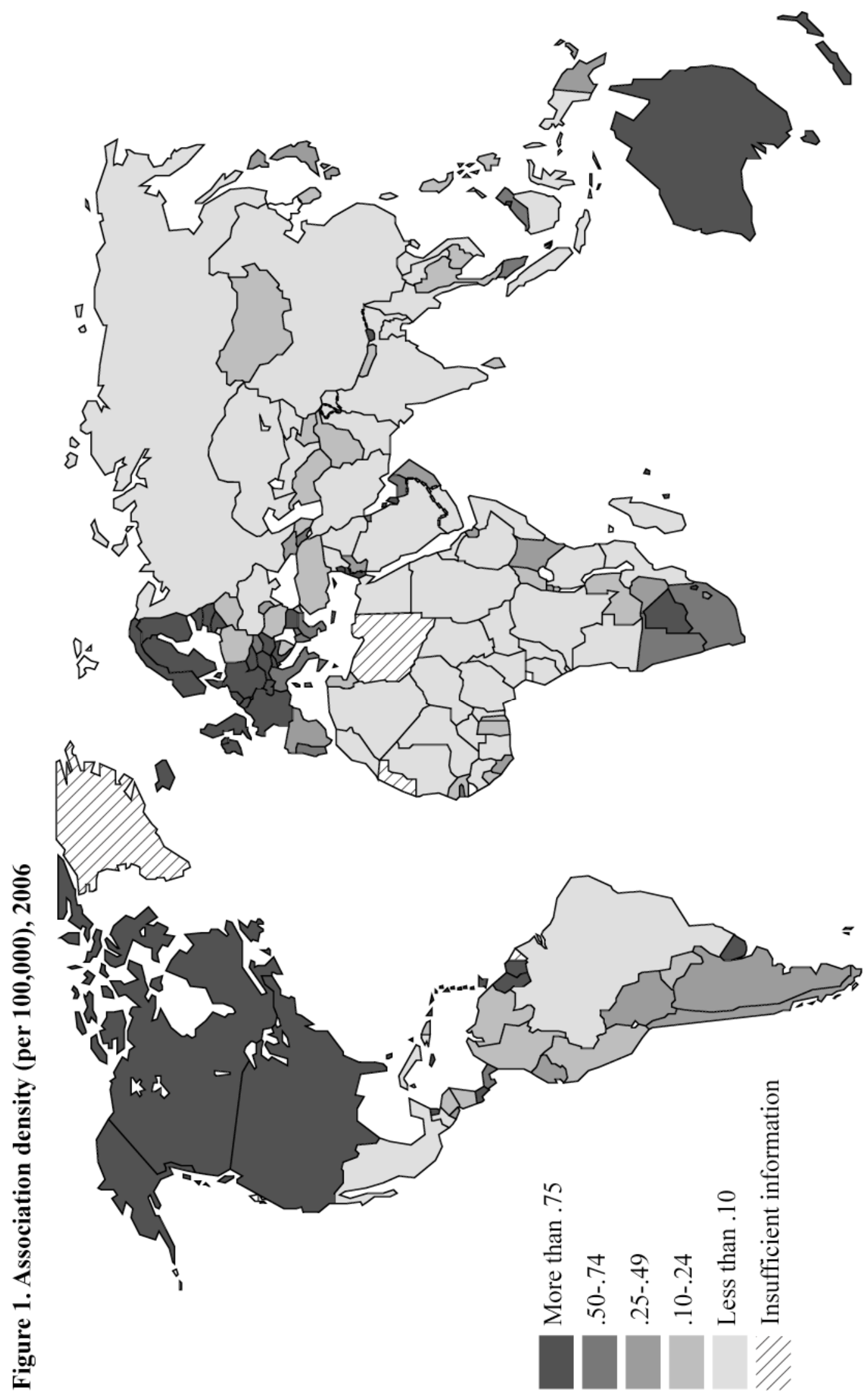




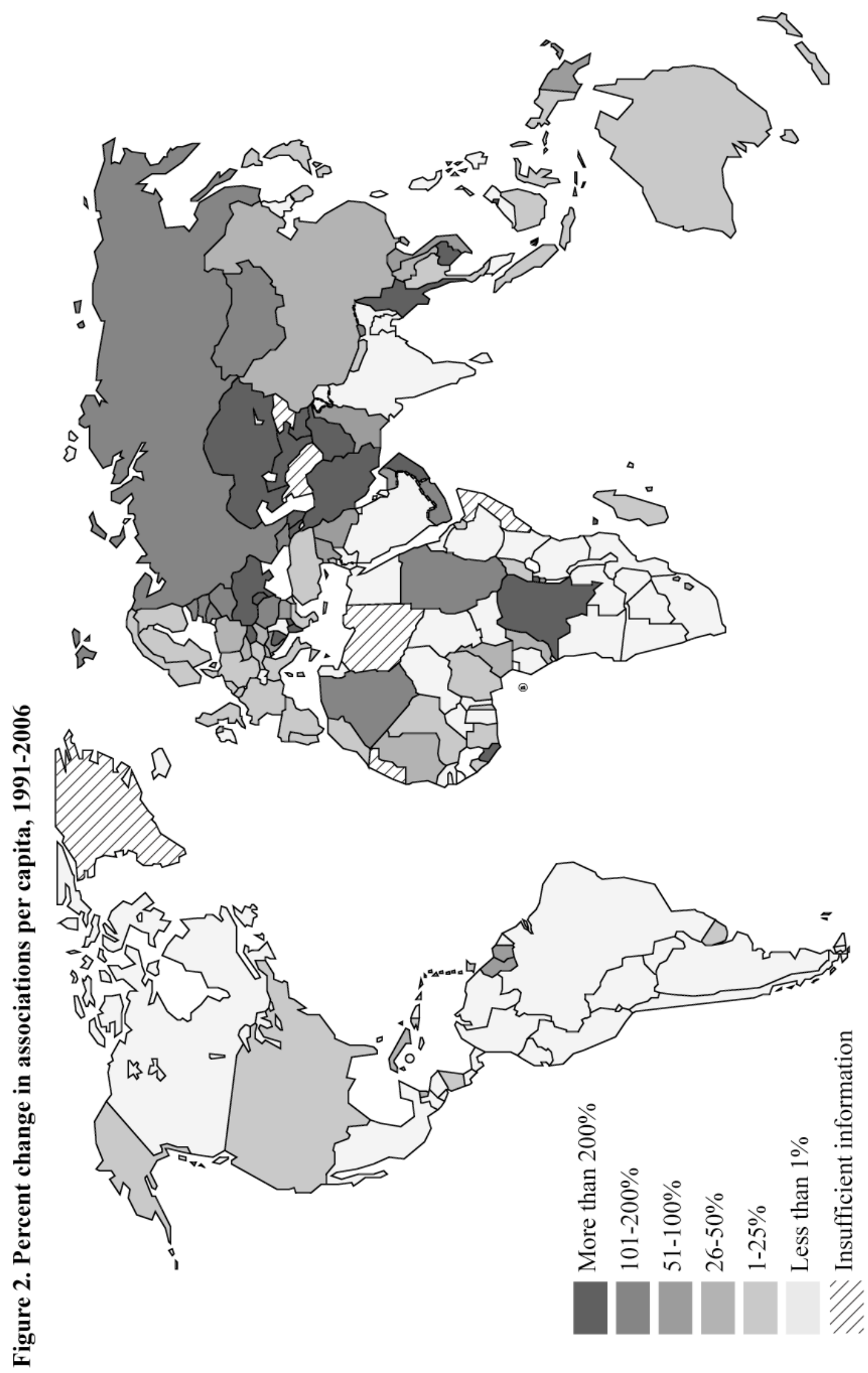

